\title{
Microglia-Mediated Neuroinflammation and Neurotrophic Factor-Induced Protection in the MPTP Mouse Model of Parkinson's Disease-Lessons from Transgenic Mice
}

\author{
Venissa Machado ${ }^{1,2,3}$, Tanja Zöller 1,3,4 , Abdelraheim Attaai ${ }^{1,3,5}$ and Björn Spittau ${ }^{1, *}$ \\ 1 Institute for Anatomy and Cell Biology, Department of Molecular Embryology, \\ Albert-Ludwigs-University Freiburg, Albertstraße 17, Freiburg 79104, Germany; \\ venissa.machado@sgbm.uni-freiburg.de (V.M.); tanja.zoeller@anat.uni-freiburg.de (T.Z.); \\ abdelraheim.attaai@anat.uni-freiburg.de (A.A.) \\ 2 Spemann Graduate School of Biology and Medicine (SGBM), Albert-Ludwigs-University Freiburg, \\ Albertstraße 19A, Freiburg 79104, Germany \\ 3 Faculty of Biology, Albert-Ludwigs-University Freiburg, Schänzlestraße 1, Freiburg 79104, Germany \\ 4 Institute for Anatomy and Cell Biology, Department of Neuroanatomy, Albert-Ludwigs-University Freiburg, \\ Albertstraße 17, Freiburg 79104, Germany \\ 5 Department of Anatomy and Histology, Faculty of Veterinary Medicine, Assiut University, \\ Assiut 71526, Egypt \\ * Correspondence: bjoern.spittau@anat.uni-freiburg.de; Tel.: +49-761-203-5092; Fax: +49-761-203-5091
}

Academic Editor: Kurt A. Jellinger

Received: 11 December 2015; Accepted: 19 January 2016; Published: 26 January 2016

\begin{abstract}
Parkinson's disease (PD) is a neurodegenerative disease characterised by histopathological and biochemical manifestations such as loss of midbrain dopaminergic (DA) neurons and decrease in dopamine levels accompanied by a concomitant neuroinflammatory response in the affected brain regions. Over the past decades, the use of toxin-based animal models has been crucial to elucidate disease pathophysiology, and to develop therapeutic approaches aimed to alleviate its motor symptoms. Analyses of transgenic mice deficient for cytokines, chemokine as well as neurotrophic factors and their respective receptors in the 1-methyl-4-phenyl-1,2,3,6-tetrahydropyridine (MPTP) model of PD have broadened the current knowledge of neuroinflammation and neurotrophic support. Here, we provide a comprehensive review that summarises the contribution of microglia-mediated neuroinflammation in MPTP-induced neurodegeneration. Moreover, we highlight the contribution of neurotrophic factors as endogenous and/or exogenous molecules to slow the progression of midbrain dopaminergic (mDA) neurons and further discuss the potential of combined therapeutic approaches employing neuroinflammation modifying agents and neurotrophic factors.
\end{abstract}

Keywords: MPTP; neuroinflammation; microglia; Parkinson's disease; neurotrophic factors; neuroprotection

\section{Introduction}

Parkinson's disease (PD) is the second most common neurodegenerative disease after Alzheimer's disease $(\mathrm{AD})$ and affects $1 \%-2 \%$ of the population over 60 years of age [1,2]. PD is characterised by a progressive loss of dopaminergic ( $\mathrm{mDA}$ ) neurons in the substantia nigra $(\mathrm{SN})$ and a subsequent decrease in dopamine levels in the basal ganglia $(\mathrm{CPu})$ [3]. This reduction in dopamine is responsible for the typical clinical symptoms of akinesia/bradykinesia, in combination with resting tremor, rigidity and gait disturbances. However, several non-motor clinical symptoms such as autonomic dysfunctions, 
anxiety, depression, cognitive impairments as well as impaired olfaction have been associated with PD and are not necessarily related to the lack of dopamine [4-6]. The histopathological hallmarks of $\mathrm{PD}$ are reduced numbers of mDA neurons and the presence of intracellular protein aggregate inclusions called Lewy bodies [7]. $\alpha$-synuclein, the main component of Lewy bodies [8], is thought to provoke intracellular stress responses in neurons eventually resulting in the degeneration of Lewy body-containing neurons. Interestingly, the appearance of Lewy bodies is not restricted to mDA neurons and has been reported in other brain areas depending on disease severity. These observations led to the Braak hypothesis, which defines PD as a neurodegenerative diseases that ascends from the dorsal motor nucleus of the vagus nerve, to lower brainstem areas including the ventral midbrain, and finally to neocortical regions [9]. However, the presence of Lewy bodies alone does not explain the onset and progression of PD [10], indicating that a secondary effect triggered by neuronal impairment might be responsible for its progressive nature. Neuroinflammatory reactions have been described in virtually all PD cases, with several studies supporting the hypothesis that microglia-mediated neuroinflammatory responses exacerbate the loss of $\mathrm{mDA}$ neurons and, thus, worsen the clinical symptoms [11,12].

In order to understand the pathomechanisms underlying PD and to recapitulate the contribution of microglia-driven inflammatory responses, toxin-based mouse models have extensively been used in the past decades [13]. The most commonly used toxins to induce degeneration of mDA neurons are 6-hydroxydopamine (6-OHDA) and 1-methyl-4-phenyl-1,2,3,6-tetrahydropyridine (MPTP), both of which are relatively selective for catecholaminergic neurons [14].

In this comprehensive review, we summarise the neuroinflammatory responses in the MPTP mouse model of PD, and highlight the contribution of neuroinflammation from a collection of studies where the outcomes of transgenic mice for cytokines/chemokines and their respective receptors have been addressed after MPTP intoxication. We further review the role of neurotrophic factors as endogenous cues to inhibit MPTP-induced neurodegeneration, and propose that future treatment strategies for PD might include a combination of neurotrophic support and molecules targeting microglia-mediated neuroinflammation.

MPTP is an analogue of the narcotic meperidine, and was accidentally discovered when drug addicts developed a Parkinsonian syndrome after intravenous injections of MPPP (1-methyl-4-phenyl-propion-oxypiperidine) with a full spectrum of clinical motor symptoms [15]. The neurotoxic effects caused by MPTP had similar clinical and neuropathological findings as those observed in PD patients, with the exception of Lewy bodies. These observations led to the establishment of MPTP as a common neurotoxin to induce Parkinsonism in several animal models [16]. When administered systemically (either as intraperitoneal or intravenous injections), MPTP easily crosses the blood-brain-barrier (BBB) owing to its lipophilic nature. Astrocytic monoamine oxidase B further converts MPTP to 1-methyl-4-phenyl-2,3-dihydropyridium (MPDP), which spontaneously oxidises to yield the polar molecule 1-methyl-4-phenylpyridinium $\left(\mathrm{MPP}^{+}\right) . \mathrm{MPP}^{+}$is then released into the extracellular space, but due its polar nature, cannot freely enter cells [17-19]. Th-ir (Tyrosine hydroxylase-immunoreactive) mDA neurons and other catecholaminergic neurons are especially sensitive to MPTP-induced degeneration due to the selective uptake of $\mathrm{MPP}^{+}$by the dopamine transporter (DAT) and noradrenaline and serotonin transporters [20-22]. After uptake into mDA neurons, $\mathrm{MPP}^{+}$binds to the vesicular monoamine transporter (VMAT) and further accumulates in the mitochondria as well as in the cytoplasm where it can interact with several enzymes [23,24]. The neurotoxic effects of MPTP are caused by an inhibition of the complex I of the electron transport chain, leading to increased reactive oxygen species production and oxidative stress [25-27].

The selective degeneration of mDA neurons by MPTP makes it one of the most commonly used toxins to induce PD in rodents. However, as rats are resistant to its effects [28,29], mice are routinely used as model organisms in this toxin paradigm. Interestingly, the inbred strain C57BL/ 6 has been shown to be more susceptible to MPTP than the BALB/c (BALB) strain $[30,31]$, and is therefore used in 
the majority of studies to date. According to the study question, different MPTP application regimes can be used and are summarised below according to Schmidt and Ferger [32] and Schober [14]:

1. Pre-symptomatic PD model: acute single MPTP application at low dose $(1 \times 10-20 \mathrm{mg} / \mathrm{kg})$.

2. Immediate onset PD model [33]: acute repetitive MPTP application at intermediate doses $(4 \times 20 \mathrm{mg} / \mathrm{kg}$ at $2 \mathrm{~h}$ intervals).

3. Sub-chronic PD model [34,35]: MPTP injections (1-2) at doses about 20-30 mg/ $\mathrm{kg}$ for up to 5 consecutive days.

4. Progressive chronic PD model [36]: daily MPTP injections at low doses (4 mg/ $\mathrm{kg}$ ) over 20 days.

It is worth mentioning that the sub-chronic and chronic models are characterised by degeneration of mDA neurons and, thus, most likely resemble the situation in human PD cases. Apart from these four treatment paradigms, several studies have used slightly modified protocols to address questions of neurodegeneration and neuroinflammation [32].

Although MPTP is one of the most potent toxins used to induce specific degeneration of mDA neurons, it has to be noted that MPTP is a hazardous and dangerous agent and users have to follow strict rules concerning storage, handling and disposal of the neurotoxin [16].

\section{Neuroinflammatory Responses in the 1-Methyl-4-phenyl-1,2,3,6-tetrahydropyridine (MPTP) Mouse Model for Parkinson's Disease}

\subsection{Temporal and Spatial Glia Reactions after MPTP Intoxication}

Systemic injections of MPTP result in a rapid onset of neuroinflammatory responses in the $\mathrm{SN}$ as well as in the $\mathrm{CPu}$. These astroglia- and microglia-mediated responses are triggered by the impairment of mDA neuron function and maintenance, making the MPTP model suitable to analyse the associated neuroinflammatory changes [37]. Due to its lipophilic nature and the ability to cross the BBB, the MPTP model has the advantage that microglia are not activated by direct injections or by mechanical manipulations of the central nervous system (CNS). This makes it superior to the 6-OHDA model, wherein the toxin has to be injected directly into the CNS parenchyma [14]. Microglial reactions have been simply categorised into M1 and M2 reactions, which in theory, resemble two opposite activation states. While M1 activation is supposed to promote acute neuroinflammation, cellular and/or neurotoxicity, M2 activation is believed to mediate anti-inflammatory effects associated with tissue regeneration and wound healing. However, these theoretical M1/M2 activation states are the end-points of a microglia activation continuum. The influence of these activation states in neurodegenerative diseases are yet only partially understood, and need to be further addressed [38].

The first studies addressing microglial reactions in the MPTP mouse model demonstrated a distinct microglia activation characterised by an increase in cell numbers and typical changes in microglia morphology, such as increased lectin staining, larger cell bodies, reduced ramification and thickening of cellular processes [39,40]. These microglial reactions could be observed in the SN and in the $\mathrm{CPu}$ during the first two weeks after MPTP intoxication. Moreover, signs of active phagocytosis and morphological features indicating secretion of biologically active substances could be detected at the ultrastructural level. Kohutnicka and colleagues further provided evidence for a delayed astrocytic response, which might also be involved in mediating the neuroinflammatory response [39]. These results suggested that microglial activation, which preceded neuron degeneration, might be involved in the progression of mDA neuron damage after MPTP intoxication. Interestingly, inhibition of microglial activation by application of minocycline, a tetracycline derivative, mitigated both the decrease of nigrostriatal mDA neurons and the formation of nitro-tyrosine produced by MPTP. Furthermore, minocycline not only prevented MPTP-induced microglial activation but also inhibited the formation of mature Il-1 $\beta$, activation of NADPH-oxidase, and inducible nitric oxide synthase (iNOS), all of which are known microglial-derived cytotoxic mediators [41].

Detailed analyses of the spatiotemporal expression of inflammatory markers indicated that Il- $1 \beta$ expression rapidly increased after MPTP intoxication and peaked at around $6 \mathrm{~h}$ [42]. Increases in 
Tumour necrosis factor $\alpha$ (Tnf- $\alpha$ ), iNos and Interferon- $\gamma($ Ifn- $\gamma$ ) were described between $6 \mathrm{~h}$ and $24 \mathrm{~h}$ after MPTP administration, whereas Il-10 expression revealed two peaks of induction; $6 \mathrm{~h}$ and 3 days after MPTP injection. Il-6 showed a delayed upregulation at 7 days post MPTP administration. This expression data is in congruence with other studies, thus corroborating the involvement of Tnf- $\alpha$, iNos, Il-1 $\beta$ and Ifn- $\gamma$ as key neuroinflammatory players after MPTP intoxication [43,44]. Moreover, the expression levels of receptors Il-1r1, Tnf- $\alpha r 1$ and Il-6r $\alpha$ were significantly increased in the SN of MPTP-treated mice, whereas no significant differences were observed in the $\mathrm{CPu}$. Yasuda and colleagues [45] reported that MPTP-sensitive C57BL/6 mice, characteristic for their propensity towards M1 microglia reactions, displayed an increase in the inflammatory markers Il-10, Il-12 p40, Ifn- $\gamma$ and Mcp-1/Ccl2 (monocyte/macrophage chemoattractant protein) in the cerebrospinal fluid. This increase in expression could not be detected in the MPTP-resilient BALB mice, indicating that the reported susceptibility of C57BL/ 6 mice for MPTP-induced mDA neurodegeneration [30] might be caused by the prominent neuroinflammatory response of C57BL/6 mice.

An increase in expression of $M c p-1 / C c l 2$ after MPTP injections has also been reported [46]. $M c p-1 / C c l 2$ was one of the first upregulated inflammatory proteins after MPTP administration, suggesting a role for $\mathrm{Mcp}-1 / \mathrm{Ccl} 2$ as a key component in the neuroinflammatory cascade. Although most studies addressed the transient effects of MPTP injections on microglial reactions, long-term effects could be observed even after 6 months of toxin administration. Microglia in the SN and the $\mathrm{CPu}$ of MPTP-treated C57BL/6 mice showed hypertrophic cell bodies as compared to control microglia, underlining that MPTP administration results in the presence of persistent activated microglia [47]. Activation of microglia in the MPTP model does not only trigger a neuroinflammatory cascade characterised by release of cytokines and chemokines, but further results in microglia-neuron interactions, referred to as gliapes, which precede mDA neurodegeneration. A study by Barcia and colleagues [48] demonstrated that activated microglia engulf $\mathrm{mDA}$ neurons in a Rock/Cdc42-dependent manner, thereby directly contributing to the decrease in mDA neurons after MPTP administration.

Apart from microglial and astroglial reactions, the latter of which is less well studied and described, peripheral immune cells also play an important role during the course of neuroinflammation in the mouse MPTP model, with reports of it infiltrating $\mathrm{CD}^{+}$and $\mathrm{CD} 8^{+} \mathrm{T}$-lymphocytes in the SN [49]. Moreover, these activated lymphocytes showed increased Lymphocyte function-associated antigen 1 (Lfa-1) and CD44 expression. Interestingly, treatment with dexamethasone, an inhibitor of T-cell infiltration and activation, reduced microglia and astroglia reactions and further ameliorated mDA neurodegeneration in the MPTP mouse model. The evidence that degeneration of mDA neurons might be regulated by the adaptive immune system was further supported by a study employing two different immunodeficient mice strains. Using Rag1 $1^{-/-}$and $\mathrm{Tcrb}^{-/-}$mice, the authors demonstrated that MPTP-induced mDA neuron degeneration was significantly reduced in the absence of T-cells [50]. However, T-cells represent a heterogeneous population of adaptive immune cells, with regulatory T-cells being primarily described as immunosuppressive, maintaining immune homeostasis and tolerance. Adoptive transfer of immunosuppressive $\mathrm{CD} 4^{+} / \mathrm{CD} 25^{+}$regulatory T-cells was able to efficiently protect mDA neurons by T-cell-mediated inhibition of microglia-driven neuroinflammation [51]. Together, these data clearly demonstrate that neuroinflammation is a hallmark of the MPTP mouse model for PD. A central question is whether microglia-mediated neuroinflammation is mechanistically involved in the progression of $\mathrm{mDA}$ neurodegeneration, and thus, studies using transgenic mice have been performed to address this question.

\subsection{Cytokine Signalling}

Cytokines are small-secreted proteins, acting as important signalling mediators under homeostatic conditions and during inflammation. Based on their structural homology and function, they are classified into chemokines, interferons, interleukins, lymphokines and tumour necrosis factor [52,53]. Chemokines attract cells to the site of infection and can thus induce gliosis in the CNS. 
The innate immune responses mediated by interferons provide a first line of defence against inflammation, and play vital roles in immune surveillance [54,55].

Ifn- $\gamma$ deletion attenuates loss of mDA neurons, their projecting fibres and dopamine levels post MPTP-intoxication [56]. Microglial activation is completely abolished in these $I f n-\gamma^{-/-}$mice. Moreover, Ifn- $\gamma^{-/-}$microglia do not show an increase in size, but do maintain lesion-induced branching behaviour after MPTP treatment. Similarly, Ifn- $\gamma^{-/-}$astrocytes failed to expand post-MPTP lesion but still exhibited their characteristic size change, indicating that Ifn- $\gamma$ is not essential for these morphological changes [57].

Deletion of $C x 3 c l 1$ (fractalkine) and its receptor $C x 3 c r 1$, leads to a dysregulation of microglial reaction and an aggravated response to MPTP [58]. Cardona and colleagues [59] reported a higher loss of Th- and Nissl-positive cells both in $C x 3 c 11^{-/-}$and $C x 3 c r 1^{-/-}$mice. Moreover, in comparison to control microglia, $\mathrm{C} x 3 \mathrm{cr}^{-/-}$microglia exhibited severe morphological changes in the SN.

In a study assessing the temporal profile of inflammatory mediators, Pattarini and colleagues observed elevated mRNA expression of monocyte chemoattractant protein 1/CC chemokine ligand 2 $(\mathrm{Mcp}-1 / \mathrm{Ccl})$ immediately after MPTP administration [46]. Interestingly, $\mathrm{Mcp}-1 / \mathrm{Ccl} 2^{-/-}$mice had significantly lower levels of macrophage inflammatory protein-1 $\alpha / C C$ chemokine ligand 3 (Mip-1 $\alpha / \mathrm{Ccl} 3$ ) and Mip-1 $\beta / \mathrm{Ccl} 4$, suggesting its role in MPTP-mediated neuroinflammation. However, mDA neuron losses in $M c p-1 / C c l 2^{-/-}$and WT mice were not significantly different. Of note, this was the only study with our search criteria in which female mice were used for the MPTP model.

Analysis of MPTP-lesioned $\mathrm{Ccl}^{-/-}$(Cysteine-cysteine chemokine ligand-2), Ccr2-/(CC chemokine receptor-2) and double $C \mathrm{cl} 2^{-/-} / \mathrm{Ccr} 2^{-/-}$mice did not reveal differences in striatal dopamine levels as compared to WT mice, suggesting that the lack of $C c l 2$ and $C c r 2$ does not protect against MPTP-induced striatal dopamine losses [60]. $C \mathrm{cr} 5^{-/-}$mice showed reduced mDA neurons and increased microglial and astrocytic activation under control conditions [61]. While WT and Ccr5 $5^{-/-}$ mice showed subtle differences in mDA neuron numbers after MPTP administration, the $C c r 5^{-/-}$mice exhibited pronounced dopamine depletion, microglial activation and behavioural deficits as compared to WT mice. Moreover, $\mathrm{Ccr} 5^{-/-}$mice exhibited an increased immunoreactivity for monoamine oxidase $\mathrm{B}$, higher p38 activation and elevated $\mathrm{MPP}^{+}$levels in the $\mathrm{SN}$ and the $\mathrm{CPu}$, indicating the importance of Ccr5 for mDA neuron survival.

Interleukins are a broad class of secreted proteins that mediate various effector functions in response to a stimulus. MPTP treated $I l-1 \mathrm{rI}^{-/-}$mice showed an aggravated loss of striatal dopaminergic innervation in the $\mathrm{CPu}$ and an increased expression of Igf-1 mRNA, indicating possible interactions between interleukins and neurotrophic factors [62]. Il- $6^{-/-}$mice also showed an increased vulnerability to MPTP in comparison to their wild-type littermates [63]. Striatal dopamine depletion and mDA neuron loss were significantly higher in $\mathrm{Il}-6^{-/-}$and $\mathrm{Il}-6^{+/-}$mice, which was also dose-dependent. Moreover, striatal astrocytes were immunoreactive for Il-6 after MPTP administration. In a subsequent paper, the same group reported a compromised and transient microglial activation in the $\mathrm{SN}$ of $I l-6^{-/-}$mice, 7 days after MPTP administration as compared to WT mice [64]. Astrocytic responses, however, did not differ between the two genotypes. Additionally, iNos expression was localised in both reactive microglia and astrocytes.

Tumour necrosis factor family (Tnf) are a group of pro-inflammatory cytokines predominantly upregulated in serum and tissues following inflammation or infections [65]. Deletion of Tnf- $\alpha$ confers protection against MPTP-induced mDA neuron loss, and a reduction of associated neuroinflammatory responses. Using Tnf- $\alpha^{-/-}$mice, Ferger and colleagues showed a complete protection of Th-fibre density in the $\mathrm{CPu}$, with a partial protection against dopamine depletion. However, neither genetic ablation, nor pharmacological inhibition of Tnf- $\alpha$ confer protection in the SN [66].

Tnf $-\alpha^{-/-}$mice also exhibit reduced leakage and better integrity of the BBB after MPTP administration [67]. Morphological changes in microglia were still observed, with reduced activated microglia numbers in Tnf- $\alpha^{-/-}$mice and an attenuated release of Il-1 $\beta$ in the $\mathrm{CPu}$, but normal release in the SN. Tnf- $\alpha^{-/-}$mice also showed an attenuation of microglia and astrocyte numbers after MPTP 
administration. Interestingly, morphological changes typical for activation were still seen in both cell types [57].

Various groups have investigated the role of Tnf receptors in the context of MPTP-induced neurodegeneration. According to Sriram and colleagues [68,69], double Tnf- $\alpha r 1^{-/-/ T n f-\alpha r 2^{-/-}}$ mice, but not individual Tnf- $\alpha r 1^{-/-}$or Tnf- $\alpha r 2^{-/-}$mice, were protected against MPTP-induced mDA neurotoxicity. Increase in MPTP-induced expression of microglial Tnf- $\alpha$ preceded striatal dopaminergic denervation and astrogliosis, which was attenuated in Tnf- $\alpha r 1^{-/-} / \operatorname{Tnf}-\alpha r 2^{-/-}$mice. On the contrary, Rousselet and colleagues failed to observe protection of mDA neurons in WT, Tnf- $\alpha r 1^{-/-}$, Tnf- $\alpha r 2^{-/-}$, or Tnf- $\alpha r 1^{-/-} / \operatorname{Tnf}-\alpha r 2^{-/-}$double mutant mice after an acute dose of MPTP [70]. However, these Tnf- $\alpha r 1^{-/-} /$Tnf- $\alpha r 2^{-/-}$double mutant mice did show diminished rotarod skills and a decline in striatal dopamine levels. Using a chronic MPTP regime, Leng et al. [71] also did not observe differences in striatal dopamine and metabolite levels between WT, Tnf- $\alpha r 1^{-/-}$and Tnf- $\alpha r 2^{-/-}$mice, underlining the influence of dose and regimes on MPTP-induced degeneration of the nigrostriatal system.

\subsection{Inflammasome Activation}

Inflammasomes are cytosolic multiprotein complexes that are activated upon diverse stimuli, resulting in the production of pro-inflammatory effector cytokines including Il-18 and Il-1 $\beta$ [72-74]. These multiprotein complexes form a part of the innate immune response, functioning as sensors and responding to pathogenic stimuli, infections and inflammatory signals [75]. Inflammasomes consist of three components: a cytosolic pattern-recognition receptor, caspase-1, and an adapter protein enabling interaction between them. Upon activation, the cytosolic receptors, including members of the NOD-like receptor (NLR) family (Nucleotide-binding oligomerisation domain receptors), undergo oligomerisation leading to the assembly of the inflammasome complex and a concomitant increase in pro-Il-1 $\beta$ and Nlrp3 levels [72,74]. This serves as a recruitment and activation platform for pro-caspase-1. Activation of caspase- 1 leads to the cleavage and release of Il- $1 \beta$ and Il-18, causing inflammatory reactions. Both the ligands and their cognate receptors are expressed in the CNS, where they modulate homeostatic and neuroinflammatory processes [76,77].

Transgenic mice expressing a dominant negative inhibitor of caspase-1 (also known as IL-1 $\beta$ convertase enzyme or ICE), are resistant to MPTP-induced neurotoxicity [78]. As compared to control mice, caspase- $1^{-/}$mice showed a significant protection against losses of dopamine and its metabolites, as well as of mDA neurons after MPTP administration. The involvement of the Nlrp3 inflammasome in PD has been recently described [79], with functional Nlrp3 inflammasome expression in microglia in response to classical inflammatory activators [80]. Moreover, $\mathrm{Nlrp}^{-/-}$mice are resistant to MPTP-induced degeneration of mDA neurons [81], with reduced circulating levels of Il-1 $\beta$ and Il-18, and an impaired caspase- 1 activation. MPTP treatment in type-2 diabetes modelled mice (ob/ob and db/db), led to an impaired insulin signalling, increased mDA neurodegeneration and glial activation in the SN [82]. This was accompanied by elevated Nlrp3 activation and Il-1 $\beta$ release, underling the role of inflammasomes in metabolic mDA neurodegeneration and possibly in PD.

Deletion of the effector cytokines, namely Il-1 $\beta$ and Il-18, also protects against MPTP-induced neuroinflammation and neurodegeneration. Il-1 $1 \alpha / \beta^{-/-}$mice showed reduced CD68-positive microglia in the $\mathrm{CPu}$ and olfactory bulb after MPTP administration [83]. Similarly, $I l-18^{-/-}$mice exhibited reduced mDA loss in the SN [84]. Although microglial activation in the $\mathrm{CPu}$ of $\mathrm{Il}-18^{-/-}$mice was comparable to that in WT mice, the duration of microglial response was shorter in $\mathrm{Il}-18^{-/-}$mice, emphasising the contribution of Il-18 to neuroinflammatory processes. Table 1 summarises the effects of cytokine and chemokine signalling-related gene deletions in the mouse MPTP model. 
Table 1. Cytokine signalling and inflammasome.

\begin{tabular}{|c|c|c|c|c|c|c|c|}
\hline Gene & Gene Description & Receptor & $\begin{array}{l}\text { Transgenic } \\
\text { Modification }\end{array}$ & $\begin{array}{c}\text { MPTP } \\
\text { Administration } \\
\text { and Dosage }\end{array}$ & Neuroinflammation & Neurodegeneration & Reference \\
\hline Ccl2 (Mcp-1) & $\begin{array}{l}\text { Chemokine (C-C motif) } \\
\text { ligand } 2 \\
\text { chemokine (C-C motif) } \\
\text { receptor } 2\end{array}$ & Ccr2 & $\begin{array}{l}\text { Mcp-1/Ccl2 homozygous } \\
\text { knockout mice } \\
\text { (B6.129S4-Ccl2tm1Rol/J) }\end{array}$ & $\begin{array}{l}4 \times 20 \mathrm{mg} / \mathrm{kg} \text { i.p. } \\
2 \mathrm{~h} \text { intervals }\end{array}$ & $\begin{array}{l}\text { No differences in RNA } \\
\text { expression of Tnf- } \alpha, \text { Il-6, Cx3cr1, } \\
\text { Tweak/Tnfsf } 12, \text { Sdf-1/Cxcl12, } \\
\text { Fn14/Tnfrsf } 12 a \text { and Cxcr4. }\end{array}$ & $\begin{array}{c}\text { No difference in Th-ir mDA } \\
\text { neuron numbers }\end{array}$ & [46] \\
\hline $\begin{array}{c}\mathrm{Ccl} 2 / \mathrm{Ccl} 3 \\
(\mathrm{Mcp}-1 / \mathrm{Mip}-1 \alpha)\end{array}$ & $\begin{array}{l}\text { Chemokine (C-C motif) } \\
\text { ligand } 2 \\
\text { Chemokine }(C-C \text { motif) } \\
\text { receptor } 2\end{array}$ & Ccr2 & $\begin{array}{l}\text { Double knockout for } \\
\text { CCL2 and CCR2 } \\
\left(\text { Ccl2 } 2^{-/} \text {Ccr } 2^{-/-}\right)\end{array}$ & $\begin{array}{l}3 \times 18.2 \mathrm{mg} / \mathrm{kg} \\
\text { s.c., } 2 \mathrm{~h} \text { intervals }\end{array}$ & Not described. & $\begin{array}{l}\text { Slight reduction in dopamine } \\
\text { and DOPAC levels }\end{array}$ & [60] \\
\hline Ccl5 & $\begin{array}{l}\text { Chemokine (C-C motif) } \\
\text { receptor } 5\end{array}$ & Ccr5 & $\mathrm{Ccr} 5^{-/-}$ & $\begin{array}{l}4 \times 15 \mathrm{mg} / \mathrm{kg} \text { i.p. } \\
1.5 \mathrm{~h} \text { intervals }\end{array}$ & $\begin{array}{l}\text { Microglia activation even under } \\
\text { baseline conditions, increased } \\
\text { Iba1 protein after MPTP. }\end{array}$ & $\begin{array}{l}\text { Reduced Th-ir mDA neuron } \\
\text { numbers and fibre density }\end{array}$ & [61] \\
\hline $\begin{array}{c}\text { Cx3cl1 } \\
\text { (Fractalkine) }\end{array}$ & $\begin{array}{c}\text { Chemokine (C-X-3-C motif) } \\
\text { ligand } 1 \\
\text { Chemokine (C-X3-C motif) } \\
\text { receptor } 1\end{array}$ & Cx3cr1 & $\begin{array}{l}\text { Cx3cl1 } 1^{-/-}, \\
\text {Cx3cr1 } \\
\text { Cx3cr1 } 1^{-1-}\end{array}$ & $\begin{array}{l}4 \times 10 \mathrm{mg} / \mathrm{kg} \text { i.p. } \\
1 \text { h intervals }\end{array}$ & $\begin{array}{c}C \times 3 c r 1^{-/-} \text {mice exhibit } \\
\text { increased microglial activation } \\
\text { in the SN after MPTP. }\end{array}$ & $\begin{array}{l}\text { Increased loss of Nissl+ und } \\
\text { Th-ir mDA neurons in } \\
C x 3 c 11^{-/-} \text {and } C \times 3 c r 1^{-/-} \\
\text {mice as compared to } \\
\text { WT mice. }\end{array}$ & [59] \\
\hline $\begin{array}{c}\text { Cx3cl1 } \\
\text { (Fractalkine) }\end{array}$ & $\begin{array}{c}\text { chemokine (C-X-3-C motif) } \\
\text { ligand } 1 \\
\text { chemokine }(C-X 3-C \text { motif }) \\
\text { receptor } 1\end{array}$ & Cx3cr1 & $\mathrm{C} \times 3 \mathrm{cl1}^{-/-}$ & $\begin{array}{l}4 \times 10 \mathrm{mg} / \mathrm{kg} \text { i.p. } \\
1 \mathrm{~h} \text { intervals }\end{array}$ & $\begin{array}{l}\text { Increased CD } 68^{+} \text {and CD11b } \mathrm{b}^{+} \\
\text {area in SNpc, increased Tnf- } \alpha \\
\text { and } 11-1 \beta \text { concentrations in VM. }\end{array}$ & $\begin{array}{l}\text { Reduced Th protein and Th-ir } \\
\text { mDA neuron numbers. }\end{array}$ & [58] \\
\hline Ifn- $\gamma$ & $\begin{array}{l}\text { Interferon- } \gamma \text { Interferon- } \gamma \\
\text { receptor }\end{array}$ & Ifn- $\gamma \mathrm{r}$ & $\begin{array}{l}\text { Ifn- } \gamma^{-/-}, \\
\text {Ifn- } \gamma r^{-/-}\end{array}$ & $\begin{array}{l}5 \times 25 \mathrm{mg} / \mathrm{kg} \text { i.p. } \\
24 \mathrm{~h} \text { intervals }\end{array}$ & No microglia activation. & $\begin{array}{l}\text { Reduced loss of Th-ir mDA } \\
\text { neurons and Th protein. }\end{array}$ & [56] \\
\hline $\begin{array}{l}\text { Il-18 (Part of the } \\
\text { inflammasome) }\end{array}$ & Interleukin-18 & - & Il-18-/- & $\begin{array}{l}4 \times 10 \mathrm{mg} / \mathrm{kg} \text { i.p., } \\
2 \mathrm{~h} \text { intervals }\end{array}$ & $\begin{array}{l}\text { Normal microglia activation } \\
\text { day } 1-3 \text {, strongly reduced } \\
\text { microglia activation on day } 7 .\end{array}$ & $\begin{array}{c}\text { No loss of Th-ir mDA } \\
\text { neurons. }\end{array}$ & [84] \\
\hline $\mathrm{Il}-1 \alpha$ & Interleukin-1 $\alpha$ & Il-1r & Il- $1 r I^{-/-}$ & $1 \times 40 \mathrm{mg} / \mathrm{kg}$ s.c. & Higher Igf-1 mRNA expression. & $\begin{array}{l}\text { Reduced DAT on and higher } \\
\text { striatal serotonin transporter } \\
\text { density. }\end{array}$ & [62] \\
\hline $\begin{array}{l}\text { Il- } 1 \alpha / \beta \text { (Part of } \\
\text { the inflammasome) }\end{array}$ & $\begin{array}{l}\text { Interleukin-1 } \alpha \\
\text { Interleukin-1 } \beta\end{array}$ & - & Il- $1 \alpha / \beta^{-/-}$ & $\begin{array}{l}4 \times 20 \mathrm{mg} / \mathrm{kg} \text { i.p. } \\
2 \mathrm{~h} \text { intervals }\end{array}$ & $\begin{array}{l}\text { Decreased percentage of CD68 } \\
\text { microglia in olfactory bulb } \\
\text { and CPu. }\end{array}$ & Not described. & [83] \\
\hline
\end{tabular}


Table 1. Cont.

\begin{tabular}{|c|c|c|c|c|c|c|c|}
\hline Gene & Gene Description & Receptor & $\begin{array}{l}\text { Transgenic } \\
\text { Modification }\end{array}$ & $\begin{array}{c}\text { MPTP } \\
\text { Administration } \\
\text { and Dosage }\end{array}$ & Neuroinflammation & Neurodegeneration & Reference \\
\hline $\begin{array}{l}\text { Il-1 } 1 \beta \text { (Part of the } \\
\text { inflammasome) }\end{array}$ & Interleukin-1 $\beta$ & - & $\begin{array}{l}\text { Dominant negative } \\
\text { inhibitor of } \\
\text { interleukin-1 } \beta \\
\text { convertase enzyme } \\
\text { (ICE) }\end{array}$ & $\begin{array}{l}4 \times 15 \mathrm{mg} / \mathrm{kg}, 2 \mathrm{~h} \\
\text { intervals }\end{array}$ & Not described. & $\begin{array}{l}\text { No reduction in dopamine, } \\
\text { DOPAC or HVA after MPTP, } \\
\text { no reduction in Th-ir cell } \\
\text { count. }\end{array}$ & [78] \\
\hline Il-6 & Interleukin-6 & - & $I l-6^{-1-}$ & $30 \mathrm{mg} / \mathrm{kg}$ & $\begin{array}{l}\text { No difference in microglial } \\
\text { response. }\end{array}$ & $\begin{array}{l}\text { Increased loss of striatal } \\
\text { dopamine levels and loss of } \\
\text { Th-ir mDA neurons. }\end{array}$ & [63] \\
\hline Il-6 & Interleukin-6 & - & $I l-6^{-/-}$ & $30 \mathrm{mg} / \mathrm{kg}$, s.c. & $\begin{array}{l}\text { Normal astrogliosis but } \\
\text { compromised microgliosis at } \\
\text { day 7; time-dependent decrease } \\
\text { in iNos expression. }\end{array}$ & - & {$[64]$} \\
\hline Nlrp3 & $\begin{array}{c}\text { NLR family, Pyrin Domain } \\
\text { Containing } 3\end{array}$ & - & $\mathrm{Nlrp3}^{-/-}$ & $\begin{array}{l}5 \times 20 \mathrm{mg} / \mathrm{kg}, \text { i.p., } \\
2 \mathrm{~h} \text { intervals }\end{array}$ & $\begin{array}{c}\text { Reduced Il-1 } \beta \text { and Il-18 } \\
\text { production; impaired caspase-1 } \\
\text { activation. }\end{array}$ & $\begin{array}{l}\text { Resistant to MPTP-induced } \\
\text { loss of Th-ir mDA neurons. }\end{array}$ & [81] \\
\hline Tnf- $\alpha$ & $\begin{array}{l}\text { Tumour necrosis factor- } \alpha \\
\text { receptor }\end{array}$ & $\begin{array}{l}\text { Tnf- } \alpha \mathrm{r} 1 \text { and } \\
\text { Tnf- } \alpha \mathrm{r} 2\end{array}$ & 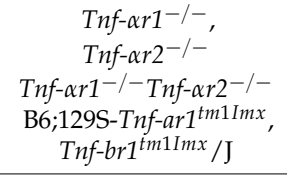 & $\begin{array}{c}1 \times 12.5 \mathrm{mg} / \mathrm{kg}, \\
\text { s.c. }\end{array}$ & $\begin{array}{l}\text { Attenuated microglial } \\
\text { activation in the CPu of } \\
\text { Tnf- } \alpha r 1^{-/} \text {Tnf- } \alpha r 2^{-/-} \text {mice. }\end{array}$ & $\begin{array}{l}\text { Reduced Th-ir mDA loss, but } \\
\text { exacerbated neuronal damage } \\
\text { in hippocampus. }\end{array}$ & [69] \\
\hline Tnf- $\alpha$ & Tumour necrosis factor- $\alpha$ & - & $\operatorname{Tnf}-a^{-/-}$ & $\begin{array}{c}\text { Acute: } 4 \times 20 \\
\text { mg/kg i.p., } 2 \mathrm{~h} \\
\text { intervals } \\
\text { Sub-acute: } 4 \times 15 \\
\text { mg/kg i.p., } 24 \mathrm{~h} \\
\text { intervals }\end{array}$ & Not described. & $\begin{array}{c}\text { Reduced losses of striatal } \\
\text { dopamine and metabolites, } \\
\text { and of striatal Th-ir fibre } \\
\text { density; no difference in Th-ir } \\
\text { and DA transporter } \\
\text { immunoreactivity in the SN; } \\
\text { lower mortality }(10 \%) .\end{array}$ & [66] \\
\hline Tnf- $\alpha$ & Tumour necrosis factor- $\alpha$ & - & $\begin{array}{c}\text { Tnf- } a^{-/-} \\
\text {(B6;129S6-TnftmlGkl/J) }\end{array}$ & $\begin{array}{l}4 \times 10 \mathrm{mg} / \mathrm{kg} \text { i.p. } \\
1 \mathrm{~h} \text { intervals }\end{array}$ & $\begin{array}{c}\text { Decreased number of activated } \\
\text { microglia, reduced } \\
\text { pro-inflammatory cytokines } \\
\text { (Tnf- } \alpha \text { and Il-1 } \beta) .\end{array}$ & $\begin{array}{l}\text { Better BBB integrity, no } \\
\text { change in Th-ir mDA } \\
\text { neuron numbers. }\end{array}$ & [67] \\
\hline Tnf- $\alpha$ & $\begin{array}{l}\text { Tumour necrosis factor- } \alpha \\
\text { receptor }\end{array}$ & $\begin{array}{l}\text { Tnf- } \alpha \mathrm{r} 1 \text { and } \\
\text { Tnf- } \alpha \mathrm{r} 2\end{array}$ & $\begin{array}{c}\text { Tnf- } \alpha r 1^{-/-}, \\
\text {Tnf- } \alpha r 2^{-/-}, \\
\text {Tnf- } \alpha r 1^{-/-} \text {Tnf- } \alpha r 2^{-/-}\end{array}$ & $\begin{array}{c}1 \times 12.5 \mathrm{mg} / \mathrm{kg} \\
\text { b.w., s.c. }\end{array}$ & $\begin{array}{l}\text { No significant upregulation of } \\
\text { Gfap in CPu of } \\
\text { Tnf- } \alpha r 1^{-/-} \text {Tnf- } \alpha r 2^{-/-} \text {mice. }\end{array}$ & $\begin{array}{l}\text { No striatal Th and dopamine } \\
\text { loss in Tnf- } \alpha r 1^{-/} \text {Tnf- } \alpha r 2^{-/-}, \\
\text {still neuronal damage } \\
\text { in hippocampus. }\end{array}$ & [68] \\
\hline
\end{tabular}


Table 1. Cont.

\begin{tabular}{|c|c|c|c|c|c|c|c|}
\hline Gene & Gene Description & Receptor & $\begin{array}{l}\text { Transgenic } \\
\text { Modification }\end{array}$ & $\begin{array}{c}\text { MPTP } \\
\text { Administration } \\
\text { and Dosage }\end{array}$ & Neuroinflammation & Neurodegeneration & Reference \\
\hline Tnf- $\alpha$ & Tumour necrosis factor $\alpha$ & $\begin{array}{l}\text { Tnf- } \alpha \mathrm{r} 1 \text { and } \\
\text { Tnf- } \alpha \mathrm{r} 2\end{array}$ & $\begin{array}{c}\text { Tnf- } \alpha r 1^{-/-}, \\
\text {Tnf- } \alpha r 2^{-/-}, \\
\text {Tnf- } \alpha r 1^{-/-} \text {Tnf- } \alpha r 2^{-/-} \\
\end{array}$ & $\begin{array}{l}4 \times 15 \mathrm{mg} / \mathrm{kg} \text { b.w., } \\
\text { i.p., } 2 \mathrm{~h} \text { intervals. }\end{array}$ & Not described. & $\begin{array}{l}\text { No difference in Th-ir mDA } \\
\text { neuron numbers; slight } \\
\text { reduction of dopamine in } \\
\text { Tnf- } \alpha r 1^{-/-} \text {Tnf- } \alpha r 2^{-/-} \text {. }\end{array}$ & [70] \\
\hline Tnf- $\alpha$ & Tumour necrosis factor $\alpha$ & $\begin{array}{c}\text { Tnf- } \alpha \mathrm{r} 1 \text { and } \\
\text { Tnf- } \alpha \mathrm{r} 2\end{array}$ & Tnf- $\alpha r 1^{-/-} / \operatorname{Tnf}-\alpha r 2^{-/-}$ & $\begin{array}{l}8 \times 15 \mathrm{mg} / \mathrm{kg} \text { b.w., } \\
\text { i.p., } 24 \mathrm{~h} \text { intervals. }\end{array}$ & Not described. & $\begin{array}{l}\text { No difference in dopamine } \\
\text { levels and DAT-ir neurons. }\end{array}$ & [71] \\
\hline $\begin{array}{l}\text { Tnf- } \alpha \\
\text { Ifn- } \gamma\end{array}$ & $\begin{array}{l}\text { Tumour necrosis factor- } \alpha \text {; } \\
\text { Interferon- } \gamma\end{array}$ & & $\begin{array}{c}\text { Ifn- } \gamma^{-/-} \\
\text {(B6.129S7-Ifngtm1Ts/J), } \\
\text { Tnf- } \alpha^{-/-}(\mathrm{B} 6.129 S-T n f . \\
\text { tm1Gkl/J) }\end{array}$ & $\begin{array}{l}1 \times 20 \mathrm{mg} / \mathrm{kg} \text { b.w., } \\
\text { i.p. }\end{array}$ & $\begin{array}{l}\text { Ifn- } \gamma^{-/-} \text {: } \text { o microgliosis but } \\
\text { morphological change in } \\
\text { microglia. Tnf- } \alpha^{-/-} \text {: only slight } \\
\text { activation of microglia. } \\
\text { Tnf- } \alpha^{-/-}, \text {Ifn- } \gamma^{-/-} \text {no } \\
\text { astrocyte activation. }\end{array}$ & $\begin{array}{l}\text { No change in Th-ir mDA } \\
\text { neuron numbers after } 24 \mathrm{~h} \text {. }\end{array}$ & [57] \\
\hline
\end{tabular}

BBB, blood brain barrier; b.w., body weight; DAT, dopamine transporter; DOPAC, 3,4-dihydroxyphenylacetic acid; Fn14, Fibroblast growth factor-inducible 14; HVA, Homovanillic acid; Igf-1, insulin-like growth factor 1; iNos, inducible Nitric oxide synthases; i.p., intraperitoneal injection; Mcp-1, Monocyte chemotactic protein 1; s.c., subcutaneus injection; Sdf-1, Stromal cell-derived factor 1; SNpc, Substantia nigra pars compacta; Th, Tyrosine hydroxylase; Tnfsf-12, Tumour necrosis factor (ligand) superfamily, member 12; Tweak, Tnf-related weak inducer of apoptosis; VM, Ventral midbrain. 


\section{Growth Factors and Neurotrophic Factors}

Neurotrophic factors are secreted proteins that play vital roles during development of the nervous system by influencing the maintenance of selective neuronal populations and supporting their survival and maturation through adulthood. Based on these properties, the potential of several neurotrophic factors has been investigated in the parkinsonian brain with the help of animal models and clinical trials [85-87]. Here, we provide an update of the neurotrophic factors used in the MPTP mouse model, with a focus on neuroprotection, and the role of glia in these neurodegenerative processes.

Brain-derived neurotrophic factor (Bdnf), a neurotrophin family member, has been shown to promote the survival of mDA neurons of the developing $\mathrm{SN}$, as well as to protect pure mDA neuron cultures from $\mathrm{MPP}^{+}$toxicity $[88,89]$. Bdnf has also been localised in nestin-positive astrocytes in the $\mathrm{CPu}$ of MPTP-lesioned mice, thus highlighting that neurotrophic factors may not only mediate their effects directly on neurons but also through glial cells [90]. Mice heterozygous for Bdnf subjected to 90 days of unrestrictive exercise, are not protected against MPTP-induced neurotoxicity of mDA neurons, suggesting that the full complement of Bdnf is essential for exercise-induced protection of mDA neurons [91]. Signalling via TrkB (Tyrosine receptor kinase B), one of the receptors for neurotrophins including Bdnf, is important for the survival of mDA neurons. Aged TrkB hypomorphic mice expressing the receptor at a quarter to a third of the normal amount show a significant loss of mDA neurons in the $\mathrm{SN}$ accompanied by an increase in reactive gliosis. Furthermore, the TrkB hypomorphic mice exhibit a significantly greater reduction in the number of $\mathrm{mDA}$ neurons after MPTP administration, indicating that a reduction in TrkB signalling increases the vulnerability of these neurons to neurotoxin-induced cell death [92]. Exogenous application of nerve growth factor (Ngf), another member of this family, has been shown to be beneficial for the nigrostriatal system by increasing the dopamine content in the CPu of MPTP-lesioned mice [93]. Moreover, Ngf and neurotrophin-3 were found to co-localise in reactive astrocytes in the CPu of MPTP-lesioned mice [94], underlining the neuroprotective roles of reactive astrocytes in PD.

The neuroprotective and neurorestorative potentials of several members of the Transforming growth factor- $\beta$ (TGF- $\beta$ ) superfamily have been investigated in the MPTP neurotoxic model [95]. Of these, Glial derived neurotrophic factor (Gdnf) has received the most attention as a potential therapeutic agent for treating PD [96,97]. Mice with null mutations for Gdnf die at birth making it impractical to assess its post-natal effects on the nigrostriatal system. Granholm and colleagues circumvented this by transplanting foetal neural tissues from $G d n f^{-/-}, G d n f^{+/-}$and WT mice into the CPu of MPTP-treated adult WT mice [98]. Grafts from $G d n f^{-/-}$foetal ventral midbrains have reduced $\mathrm{mDA}$ neuron numbers and fibre outgrowth. Moreover, these grafts can be rescued by pre-incubation with Gdnf before grafting, highlighting its neurorestorative effects in this model. Exogenous application of Gdnf either via stereotactic injections [99-101], via gelfoam application [102], or via a lentiviral construct [103], have shown to be neuroprotective for the MPTP-lesioned nigrostriatal system. Of note, lentiviral mediated expression of Gdnf under a macrophage specific promoter, ameliorated MPTP-induced neurodegeneration in recipient mice, via putative neuroprotective effects of Gdnf expressing macrophages or microglia on mDA neurons [103]. Similarly, bone marrow-derived microglial delivery of Neurturin (Ntn), a member of the Gdnf family of ligands, also led to a significant protection of mDA neurons and their fibre terminals post MPTP administration [104]. Conditional deletion of the Gdnf receptor Ret (Rearranged during transfection) did not increase the vulnerability of mDA neurons after MPTP lesion, but was essential for the reappearance of fibres in the CPu [105]. Moreover, MPTP treated mice haploinsufficient for the Gdnf receptor Gfra1 (Glial cell line derived neurotrophic factor family receptor $\alpha 1$ ), showed increased death of mDA neurons accompanied by an elevated inflammatory response consisting of reactive microglia and CD45-ir in the SN [106]. Given the importance of Tgf- $\beta \mathrm{s}$ in the developing nigrostriatal system [107] and its requirement to elicit neuroprotective effects in conjunction with Gdnf $[108,109]$, Schober and colleagues simultaneously applied exogenous Gdnf in combination with Tgf- $\beta$ neutralising antibodies to an MPTP lesioned nigrostriatal system [102]. The neuroprotective effects of Gdnf on MPTP-lesioned mDA neurons and 
their terminal fibres were abolished in the absence of Tgf- $\beta$. This emphasises the requirement of Tgf- $\beta$ as an essential co-trophic factor for Gdnf in the MPTP mouse model of PD. Mice haploinsufficient for Tgf- $\beta 2$ however do not show a reduction in MPTP-induced striatal dopamine depletion [110]. On the contrary, over expression of Tgf- $\beta 1$ in the nigrostriatal system of MPTP lesioned mice caused significant reduction in the numbers of mDA neurons and an extensive depletion of dopamine levels in the $\mathrm{CPu}[111]$.

The potential of gliotrophic factors such as the Fibroblast growth factor (Fgf), Epidermal growth factor (Egf) and Insulin-like growth factor (Igf) have also been investigated in the MPTP mouse model of PD. Intracerebroventricular infusion of Egf partially enhanced striatal dopamine levels and further increased the activity of Th in MPTP treated mice, suggesting a neurotrophic role for mDA neurons [112]. Fgf can induce glial proliferation in vivo and in vitro, and is upregulated following brain injury as an essential molecule for scar formation [97]. Stereotactic injections of Fgf-1 (also known as acidic Fgf) into the $\mathrm{CPu}$ of MPTP-lesioned young and old mice, led to a recovery of dopamine concentrations and striatal fibre densities in young but not in old mice, indicating that the benefits of exogenous application declined with increasing age [113]. Exogenous application of Fgf-2 via a striatal gelfoam implantation, or administration of human recombinant Fgf in MPTP treated mice, ameliorated toxin-induced degeneration the nigrostriatal system [114-116]. Although Fgf-2 application did not lead to a sustained increase in astroglial numbers [117], Fgf-2-ir was observed in both astroglial and microglial cells post MPTP administration, implying the neuroprotective functions of glial cells in this paradigm [118]. However, in spite of its prominent role as a neurotrophic factor for mDA neurons, MPTP lesioned $F g f-2^{-/}$mice do not exhibit differences in dopamine levels or mDA neuron numbers as compared to lesioned WT littermates [119]. This may be partly attributed to compensatory effects by another member of the Fgf family, or by another growth factor family altogether.

Igfs are essential trophic factors required for the growth and development of the embryonic brain, with neuromodulatory functions in the adult brain [97,120]. The protein encoded by the gene Igf- 1 is served by its receptor Igf- $1 \mathrm{r}$, a transmembrane tyrosine-kinase receptor homologous to the insulin receptor. Mice haploinsufficient for the $I g f-1 r$ administered with MPTP show exacerbated losses of mDA neurons as compared to their WT littermates. Moreover, the $I g f-1 r^{+/-}$mice exhibit an increased microglial inflammatory response to the neurotoxin and a down-regulation of several anti-inflammatory pathways under control conditions, indicating that the Igf signalling pathway/s can reduce neuroinflammatory responses and sensitivity of mDA neurons to MPTP-induced inflammation [121].

Members of the Platelet derived growth factor (Pgdf) family also act via tyrosine kinase receptors and regulate cellular proliferation, growth and differentiation $[97,122]$. The Pdgf-bb isoform has been shown to increase the survival of cultured mDA neurons and induce neurite outgrowth $[123,124]$. Intracerebroventricular administration of Pgdf-bb following MPTP lesion, restored striatal dopamine transporter binding sites and Th expression, and led to an increase in cell proliferation in the $\mathrm{CPu}$ of lesioned mice [122]. The ability of Colony stimulating factors (Csfs), namely granulocyte Csf (G-Csf) and Granulocyte-Macrophage Csf (GM-Csf), has recently been realised in the diseased CNS. While G-Csf specifically promotes neutrophil proliferation and maturation, GM-Csf has effects on multiple cell lineages including macrophages and eosinophils [125]. G-Csf is commonly used to treat neutropenia, and has been shown to have roles in the challenged nervous system [126,127]. Exogenous administration of G-Csf in MPTP treated mice rescued mDA neuron death and recovered striatal dopamine levels $[128,129]$. Moreover, this neuroprotective effect could be elicited by modulation of Bcl-2 and Bax expression in the injured nigrostriatal system [130]. MPTP-lesioned mice post-treated with G-Csf showed a reduced microglial burden in the $\mathrm{CPu}$, indicating a putative neuroprotective and restorative effect [129]. In the CNS, GM-Csf is produced by resident astroglial cells, fibroblasts, endothelial cells and cells of the myeloid lineage [125]. MPTP-lesioned mice receiving exogenous GM-Csf showed reduced mDA loss, increase in dopamine levels, and an improved motor 
performance [131], with reductions in microglial activation and responses, and an induction of regulatory T-cells suggestive of the neuroprotective effects of GM-Csf [132].

The recently discovered Cerebral dopamine neurotrophic factor (Cdnf) is a member of the conserved Cdnf/Manf family of neurotrophic factors, and has been shown to protect and rescue 6-OHDA-lesioned mDA neurons in vivo [133,134]. As in the MPTP model, Cdnf administered before or after MPTP lesion led to an increase in striatal Th-fibre densities and increased neuron survival, with improved locomotor behaviour, thus underscoring its neuroprotective and neurorestorative effects on the injured nigrostriatal system [135]. A comprehensive overview of growth factors and neurotrophic factors is given in Table 2 .

\section{Concluding Remarks}

In the present review, we have highlighted the involvement of microglia-mediated neuroinflammation and effects of neurotrophic factors in the mouse MPTP model of PD. Figure 1 summarises the complex interactions between neurons, microglia and astrocytes. The studies performed with respective transgenic mice demonstrate that microglia reactions and the subsequent release of cytokines contribute to an increased degeneration of mDA neurons after MPTP administration. However, most of the studies showed insufficient protection of mDA neurons when cytokines or their respective receptors had been silenced, indicating that MPTP-driven neurotoxicity is enhanced, but not caused by neuroinflammation. Neurotrophic factors are, notwithstanding initial failed attempts, the most promising therapeutic option to slow progression of mDA neuron loss in PD patients. Interestingly, studies using either exogenous application of neurotrophic factors or transgenic mice, with factor and/or receptor deletions, support the potential of neurotrophic factors as protective cues in the mouse MPTP model. Thus, we propose that future therapeutic strategies should consider inhibition of neuroinflammation and direct neuroprotection as two separate phenomena, which can be modified therapeutically. Based on the current data, combinations of potent neurotrophic factors and inhibitors, or modulators of microglial reactions, might be appropriate and promising to slow the progression of PD. 
Table 2. Growth factors and neurotrophic factors.

\begin{tabular}{|c|c|c|c|c|c|c|c|}
\hline Gene & Gene Description & $\begin{array}{c}\text { Transgenic } \\
\text { Mouse/Exogenous } \\
\text { Treatment } \\
\end{array}$ & $\begin{array}{l}\text { Transgenic } \\
\text { Modification }\end{array}$ & $\begin{array}{l}\text { MPTP Administration and } \\
\text { Dosage }\end{array}$ & Neuroinflammation & Neurodegeneration & Reference \\
\hline Bdnf & $\begin{array}{l}\text { Brain-derived neurotrophic } \\
\text { factor }\end{array}$ & $B d n f^{+/-}$mice & Haploinsufficient & 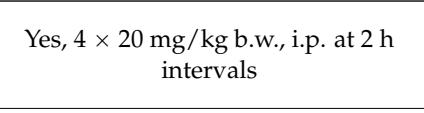 & Not described. & $\begin{array}{l}\text { Bdnf } f^{+/-} \text {mice do not show } \\
\text { differences compared to } \\
\text { WT mice. }\end{array}$ & [91] \\
\hline Cdnf & $\begin{array}{l}\text { Cerebral dopamine } \\
\text { neurotrophic factor }\end{array}$ & $\begin{array}{l}\text { Pre and post treatment } \\
\text { with Cdnf } 5 \mu \mathrm{g} / \mu \mathrm{L} \\
\text { (bilateral striatal } \\
\text { injections) before and } \\
\text { after MPTP }\end{array}$ & None & $\begin{array}{l}\text { Yes, } 4 \times 15 \mathrm{mg} / \mathrm{kg} \text { b.w, i.p. for } \\
\text { pre-treatment and } 20 \mathrm{mg} / \mathrm{kg} \text { b.w, i.p. } \\
\text { for post-treatment respectively }\end{array}$ & Not described. & $\begin{array}{l}\text { Exogenous Cdnf proves } \\
\text { neuroprotective and } \\
\text { neurorestorative for the NS } \\
\text { system. }\end{array}$ & [135] \\
\hline Egf & Epidermal growth factor & $\begin{array}{l}\text { Infusion of Egf } \\
5 \mu \mathrm{g} / \text { week }\end{array}$ & None & Yes, $7 \times 30$ mg/kg b.w., i.p. & Not described. & $\begin{array}{c}\text { Partial restoration of } \\
\text { dopamine and DOPAC. }\end{array}$ & [112] \\
\hline aFgf or Fgf-1 & $\begin{array}{l}\text { acidic Fgf or Fibroblast growth } \\
\text { factor-1 }\end{array}$ & $\begin{array}{l}\text { Stereotactic injections of } \\
\quad \mathrm{aFgf} 0.5 \mu \mathrm{g} / \mu \mathrm{L}\end{array}$ & None & Yes, $4 \times 20$ mg/kg b.w., i.p. & Not described. & $\begin{array}{c}\text { Dopamine concentration and } \\
\text { striatal fibre density partially } \\
\text { recovered in young mice } \\
(8 \mathrm{w}) \text { but not in old mice } \\
(12 \mathrm{~m}) .\end{array}$ & [113] \\
\hline bFgf or Fgf-2 & Fibroblast growth factor-2 & $F \& f-2^{-/-}$ & Complete knockout & Yes, $3 \times 20$ mg/kg b.w., i.p. & Not described. & $\begin{array}{l}\text { No significant differences in } \\
\text { the NS system between WT } \\
\text { and } F g f-2^{-/-} \text {mice. }\end{array}$ & [119] \\
\hline Fgf-2 & Fibroblast growth factor-2 & $\begin{array}{l}\text { Gelfoam containing } 4 \mu \mathrm{g} \\
\text { Fgf-2 or cytochrome-c }\end{array}$ & None & Yes, $3 \times 20$ mg/kg b.w., i.p. & $\begin{array}{l}\text { Co-staining of Fgf- } 2 \text { with } \\
\text { presumed microglial } \\
\text { cells. }\end{array}$ & Not described. & [118] \\
\hline Fgf-2 & Fibroblast growth factor-2 & $\begin{array}{l}\text { Gel foam containing } 4 \mu \mathrm{g} \\
\text { Fgf-2 or cytochrome-c }\end{array}$ & None & Yes, $3 \times 20$ mg/kg b.w., i.p. & Not described. & $\begin{array}{l}\text { Moderates reduction of } \\
\text { striatal dopamine and } \\
\text { reverses losses of Th-ir } \\
\text { mDA neurons. }\end{array}$ & [114] \\
\hline Fgf-2 & Fibroblast growth factor-2 & $\begin{array}{l}\text { Gel foam containing } 4 \mu \mathrm{g} \\
\text { Fgf- } 2 \text { or cytochrome-c }\end{array}$ & None & Yes, $3 \times 20 \mathrm{mg} / \mathrm{kg}$ b.w., i.p. & $\begin{array}{l}\text { No excessive reactive } \\
\text { astrocytosis after Fgf- } 2 \\
\text { application. }\end{array}$ & $\begin{array}{l}\text { Striatal dopamine content } \\
\text { was checked to asses } \\
\text { MPTP effect. }\end{array}$ & [117] \\
\hline Fgf-2 & Fibroblast growth factor-2 & $\begin{array}{l}\text { Intraventricular infusion } \\
\text { of hrFGF-22 } \mu \mathrm{g} / 24 \mathrm{~h}\end{array}$ & None & Yes, $40 \mathrm{mg} / \mathrm{kg}$ b.w., s.c & $\begin{array}{l}\text { hrFGF-2 induces increase } \\
\text { in astroglial reaction and } \\
\text { numbers in } \mathrm{SN} \text { and } \mathrm{CPu} \text {. }\end{array}$ & $\begin{array}{l}\text { hrFGF-2 treatment reduced } \\
\text { MPTP-induced losses of } \\
\text { mDA neurons and fibres. } \\
\text { Locomotor activity was fully } \\
\text { recovered after hrFGF-2 } \\
\text { treatment. }\end{array}$ & [115] \\
\hline G-Csf & $\begin{array}{l}\text { Granulocyte-colony } \\
\text { stimulating factor }\end{array}$ & $8 \times 250 \mu \mathrm{g} / \mathrm{kg}$, b.w., s.c. & None & Yes, $5 \times 30 \mathrm{mg} / \mathrm{kg}$ b.w., i.p. & $\begin{array}{l}\text { G-csf treatment after } \\
\text { MPTP reduced microglial } \\
\text { burden in the CPu. }\end{array}$ & $\begin{array}{l}\text { G-csf treatment after MPTP } \\
\text { improved rotarod } \\
\text { performance. }\end{array}$ & [129] \\
\hline
\end{tabular}


Table 2. Cont.

\begin{tabular}{|c|c|c|c|c|c|c|c|}
\hline Gene & Gene Description & $\begin{array}{c}\text { Transgenic } \\
\text { Mouse/Exogenous } \\
\text { Treatment }\end{array}$ & $\begin{array}{c}\text { Transgenic } \\
\text { Modification }\end{array}$ & $\begin{array}{l}\text { MPTP Administration and } \\
\text { Dosage }\end{array}$ & Neuroinflammation & Neurodegeneration & Reference \\
\hline Gdnf & $\begin{array}{l}\text { Glial derived neurotrophic } \\
\text { factor }\end{array}$ & $\begin{array}{c}\text { Transplants of foetal } \\
\text { neural tissues }\left(G d n f^{-/-}\right. \\
\text {or } G d n f^{-/+} \text {or } G d n f^{+/-} \text {) } \\
\text { into MPTP treated adult } \\
\text { WT mice }\end{array}$ & $\begin{array}{c}\mathrm{Gdnf}^{-/-} \text {or } \\
\mathrm{Gdnf}^{+/-} \text {foetal } \\
\text { neural tissues } \\
\text { transplanted into } \\
\text { ventral CPu of } \\
\text { MPTP lesioned WT } \\
\text { mice }\end{array}$ & Yes, $4 \times 30 \mathrm{mg} / \mathrm{kg} /$ day & Not described. & $\begin{array}{c}\text { Gdnf }-/- \text { grafts } \\
\text { pre-incubated with Gdnf } \\
\text { show increased Th-ir mDA } \\
\text { neuron numbers. }\end{array}$ & [98] \\
\hline Gdnf & $\begin{array}{l}\text { Glial derived neurotrophic } \\
\text { factor }\end{array}$ & $\begin{array}{l}\text { Unilateral stereotactic } \\
\text { injections of } \mathrm{Gdnf} 5 \mathrm{~g} / \mu \mathrm{L}\end{array}$ & None & Yes, $4 \times 20 \mathrm{mg} / \mathrm{kg}$ b.w., i.p. & Not described. & $\begin{array}{l}\text { Gdnf administration induces } \\
\text { recovery of the NS system in } \\
\text { both young and aged mice. }\end{array}$ & [99] \\
\hline Gdnf & $\begin{array}{l}\text { Glial derived neurotrophic } \\
\text { factor }\end{array}$ & $\begin{array}{l}\text { Intracerebral injections of } \\
\text { Gdnf ( } 5 \mu \mathrm{g} / \mu \mathrm{L}) \text { before } \\
\text { and after MPTP }\end{array}$ & None & Yes, $2 \times 40 \mathrm{mg} / \mathrm{kg}$ b.w., s.c. & Not described. & $\begin{array}{l}\text { Protection of mDA neurons; } \\
\text { recovery of Th fibres and } \\
\text { dopamine in the CPu. Motor } \\
\text { behaviour increased above } \\
\text { normal levels. }\end{array}$ & [100] \\
\hline Gdnf & $\begin{array}{l}\text { Glial derived neurotrophic } \\
\text { factor }\end{array}$ & $\begin{array}{l}\text { Intrastriatal injections of } \\
\text { Gdnf } 2 \mu \mathrm{g} / \mu \mathrm{L}\end{array}$ & None & Yes, $7 \times 35 \mathrm{mg} / \mathrm{kg}$, b.w., s.c. & Not described. & $\begin{array}{l}\text { Increased locomotor activity, } \\
\text { striatal dopamine and } \\
\text { metabolite levels, Increase in } \\
\text { Th-ir mDA neurons. }\end{array}$ & {$[101]$} \\
\hline Gdnf & $\begin{array}{l}\text { Glial derived neurotrophic } \\
\text { factor }\end{array}$ & $\begin{array}{l}\text { Gdnf lentiviral construct } \\
\text { in a macrophage-specific } \\
\text { synthetic promoter }\end{array}$ & None & $\begin{array}{l}\text { Yes, } 15 \mathrm{mg} / \mathrm{kg} \text { b.w., free base MPTP } \\
\text { on day } 1,25 \mathrm{mg} / \mathrm{kg} \text { b.w., on day } 2, \\
\text { and } 30 \mathrm{mg} / \mathrm{kg} \text { b.w., on days } 3-7, \text { s.c. }\end{array}$ & $\begin{array}{l}\text { Putative neuroprotective } \\
\text { effects of Gdnf expressing } \\
\text { macrophage/microglia } \\
\text { on Th-ir mDA neurons. }\end{array}$ & $\begin{array}{l}\text { Macrophage-mediated Gdnf } \\
\text { treatment ameliorated } \\
\text { MPTP-induced degeneration } \\
\text { of mDA neurons and Th fibre } \\
\text { terminals, stimulated axon } \\
\text { regeneration, and reversed } \\
\text { hypoactivity in the open } \\
\text { field test. } \\
\end{array}$ & [103] \\
\hline Gdnf & $\begin{array}{l}\text { Glial derived neurotrophic } \\
\text { factor }\end{array}$ & $\begin{array}{l}\text { Gel foam containing } \\
1 \mu \mathrm{g} / \mu \mathrm{L} \text { Gdnf or } \\
\text { cytochrome-c }\end{array}$ & None & Yes, $3 \times 20 \mathrm{mg} / \mathrm{kg}$ b.w., i.p. & Not described. & $\begin{array}{l}\text { Exogenous Gdnf reduced } \\
\text { loss of striatal DA fibres. }\end{array}$ & {$[102]$} \\
\hline Gfr $\alpha 1$ & $\begin{array}{l}\text { Gdnf receptor (Glial cell line } \\
\text { derived neurotrophic factor } \\
\text { family receptor } \alpha 1 \text { ) }\end{array}$ & Gfr $\alpha 1^{+/-}$ & $\begin{array}{c}\text { Haploinsufficient; } \\
\text { substitution with } \\
\text { phosphoglycerate } \\
\text { kinase } \\
\end{array}$ & Yes, $4 \times 20 \mathrm{mg} / \mathrm{kg}$ b.w., i.p. & $\begin{array}{l}\text { Higher CD45-ir, } \\
\text { microglial response in the } \\
\text { SN. }\end{array}$ & $\begin{array}{l}\text { Increase in Th-ir mDA } \\
\text { neuron death. }\end{array}$ & [106] \\
\hline Gm-Csf & $\begin{array}{l}\text { Granulocyte-macrophage-colony } \\
\text { stimulating factor }\end{array}$ & $5 \times 50 \mu \mathrm{g} / \mathrm{kg}$ i.p. & None & Yes, $4 \times 16 \mathrm{mg} / \mathrm{kg}$ b.w., s.c. & $\begin{array}{l}\text { Gm-csf pre-treatment } \\
\text { altered microglial } \\
\text { morphology (reduced } \\
\text { microgliosis) and Treg } \\
\text { induction. }\end{array}$ & $\begin{array}{l}\text { Neuroprotection of Th-ir } \\
\text { mDA neurons and striatal } \\
\text { fibres by adoptive transfer of } \\
\text { Gm-Csf-induced Treg to } \\
\text { MPTP mice. }\end{array}$ & [132] \\
\hline
\end{tabular}


Table 2. Cont

\begin{tabular}{|c|c|c|c|c|c|c|c|}
\hline Gene & Gene Description & $\begin{array}{c}\text { Transgenic } \\
\text { Mouse/Exogenous } \\
\text { Treatment }\end{array}$ & $\begin{array}{l}\text { Transgenic } \\
\text { Modification }\end{array}$ & $\begin{array}{l}\text { MPTP Administration and } \\
\text { Dosage }\end{array}$ & Neuroinflammation & Neurodegeneration & Reference \\
\hline Igf-1r & $\begin{array}{l}\text { Insulin-like growth factor-1 } \\
\text { receptor }\end{array}$ & $\operatorname{Igf}-1 r^{+/-}$ & Haploinsufficient & $\begin{array}{c}\text { Yes, } 2 \times 30 \mathrm{mg} / \mathrm{kg} \text { b.w., i.p. at } 3 \mathrm{~h} \\
\text { intervals }\end{array}$ & $\begin{array}{l}\text { Increase in } \\
\text { neuroinflammatory } \\
\text { responses (particularly } \\
\text { microglia numbers in } \\
\text { SNpc and SNr). }\end{array}$ & $\begin{array}{l}\text { Increase in Th-ir mDA } \\
\text { neuron death. }\end{array}$ & [121] \\
\hline Ngf & Nerve growth factor & $\begin{array}{l}\text { Stereotactic injections of } \\
0.4 \mu \mathrm{g} / \mu \mathrm{L} \text { Ngf into the } \\
\text { right ventricle }\end{array}$ & None & Yes, $5 \times 30 \mathrm{mg} / \mathrm{kg}$ b.w., i.p. & Not described. & $\begin{array}{c}\text { Restoration of dopamine and } \\
\text { HVA levels after Ngf } \\
\text { injections. }\end{array}$ & [93] \\
\hline Ntn & Neurturin & $\begin{array}{l}\text { Ntn lentiviral construct in } \\
\text { a microglia specific } \\
\text { synthetic promoter }\end{array}$ & None & $\begin{array}{l}\text { Yes, } 15 \mathrm{mg} / \mathrm{kg} \text { b.w., free base MPTP } \\
\text { on day } 1,25 \mathrm{mg} / \mathrm{kg} \text { b.w., on day 2, } \\
\text { and } 30 \mathrm{mg} / \mathrm{kg} \text { b.w., on days } 3-7, \text { s.c. }\end{array}$ & $\begin{array}{l}\text { Neuroprotective effects of } \\
\text { Ntn expressing microglia } \\
\text { on mDA neurons. }\end{array}$ & $\begin{array}{l}\text { Reduction in MPTP-induced } \\
\text { degeneration of mDA } \\
\text { neurons in the } \mathrm{SN} \text { and fibre } \\
\text { terminals in the } \mathrm{CPu} \text {. }\end{array}$ & [104] \\
\hline Pdgf & Platelet derived growth factor & $\begin{array}{c}\text { Pdgf-bb delivery } \\
\text { (36 ng/day) for } 2 \mathrm{w} \text { into } \\
\text { the right lateral ventricle } \\
\text { via osmotic pumps }\end{array}$ & None & $\begin{array}{l}\text { For cell proliferation: } 4 \times 15 \mathrm{mg} / \mathrm{kg} \\
\text { b.w., i.p. For neurorestoration } \\
1 \times 40 \mathrm{mg} / \mathrm{kg} \text { b.w., s.c. }\end{array}$ & Not described. & $\begin{array}{l}\text { Pgdf-bb administration lead } \\
\text { to an increase in striatal Th } \\
\text { expression and DAT sites. }\end{array}$ & [122] \\
\hline Ret & $\begin{array}{l}\text { Gdnf receptor (rearranged } \\
\text { during transfection) }\end{array}$ & Dat-Ret $t^{1 \mathrm{x} / \mathrm{lx}}$ & $\begin{array}{c}\text { Conditional } \\
\text { knockout }\end{array}$ & Yes, $5 \times 30 \mathrm{mg} / \mathrm{kg}$ b.w., i.p. & $\begin{array}{l}\text { No difference in } \\
\text { MPTP-induced } \\
\text { astrogliosis in CPu. }\end{array}$ & $\begin{array}{l}\text { Ret deficiency does not } \\
\text { increase MPTP vulnerability } \\
\text { in the SN, but is essential for } \\
\text { regeneration in the CPu. }\end{array}$ & [105] \\
\hline Tgf- $\beta 2$ & $\begin{array}{l}\text { Transforming growth } \\
\text { factor- } \beta 2\end{array}$ & $T g f-\beta 2^{+/-}$ & Haploinsufficient & Yes, $40+20 \mathrm{mg} / \mathrm{kg}$ b.w., s.c. & Not described. & $\begin{array}{l}\text { Marginally reduced Th-ir } \\
\text { mDA neurons. Reduced } \\
\text { striatal dopamine turnover. }\end{array}$ & [110] \\
\hline Tgf- $\beta$ & Transforming growth factor $-\beta$ & $\begin{array}{l}\text { Gel foam containing anti } \\
\text { Tgf- } \beta \text { pan mAB or } \\
\text { isotype control mouse } \\
\text { IgG }(5 \mu \mathrm{g})\end{array}$ & None & Yes, $3 \times 20 \mathrm{mg} / \mathrm{kg}$ b.w., i.p. & Not described. & $\begin{array}{l}\text { Simultaneous application of } \\
\text { Gdnf and Tgf- } \beta \text { neutralising } \\
\text { antibodies abolished the } \\
\text { neuroprotective effects } \\
\text { of Gdnf. }\end{array}$ & [102] \\
\hline Tgf- $\beta 1$ & $\begin{array}{l}\text { Transforming growth } \\
\text { factor- } \beta 1\end{array}$ & $\begin{array}{l}\text { AAV- mediated Tgf- } \beta 1 \\
\text { overexpression }\end{array}$ & None & Yes, $30 \mathrm{mg} / \mathrm{kg}$ b.w., s.c. & Not described. & $\begin{array}{l}\text { Overexpression of Tgf- } \beta 1 \text { in } \\
\text { the NS aggravates the } \\
\text { Parkinsonian state caused by } \\
\text { MPTP injury in adult mice. }\end{array}$ & [111] \\
\hline TrkB & $\begin{array}{l}\text { Bdnf receptor (Tyrosine } \\
\text { receptor kinase B) }\end{array}$ & $\begin{array}{c}\text { TrkB hypomorphic } \\
\text { mutant, fBneo/fBneo } \\
\text { (expresses TrkB at } \\
1 / 4-1 / 3 \text { of the normal } \\
\text { amount) }\end{array}$ & $\begin{array}{l}\text { Conditional } \\
\text { knockout }\end{array}$ & Yes, $5 \times 25 \mathrm{mg} / \mathrm{kg}$ b.w., i.p. & $\begin{array}{c}\text { Increased reactive } \\
\text { astrogliosis in the CPu of } \\
\text { mutant mice. }\end{array}$ & $\begin{array}{l}\text { Mutant mice exhibit selective } \\
\text { and late neurodegeneration. } \\
\text { mDA neurons show } \\
\text { enhanced vulnerability } \\
\text { to MPTP. }\end{array}$ & [92] \\
\hline
\end{tabular}




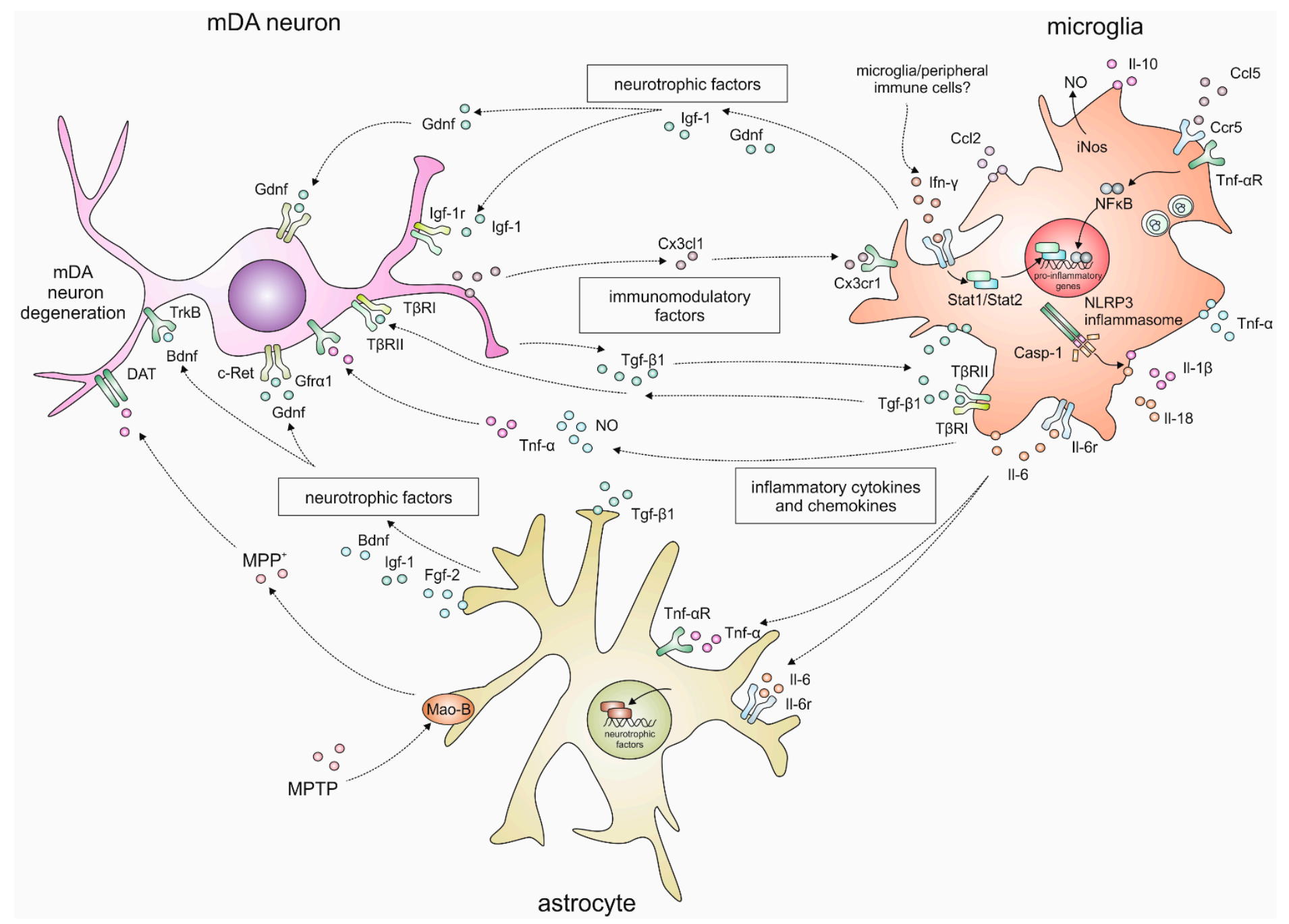

Figure 1. Schematic overview of the complex interactions between mDA neurons, microglia and astroglia after MPTP applications in mice. 
Acknowledgments: This study was supported by the Excellence Initiative of the German Research Foundation (GSC-4 Spemann Graduate School, grant to Venissa Machado), Intramural funding of the Medical Faculty of the University of Freiburg (Forschungskommission, grant to Tanja Zöller), Egyptian Ministry of Higher Education (grant to Abdelraheim Attaai) and grants from the Deutsche Forschungsgemeinschaft (SP 1555/2-1 to Björn Spittau). We apologise for studies that were not cited due to space constraints or an oversight on our part.

Author Contributions: Venissa Machado, Tanja Zöller, Abdelraheim Attaai and Björn Spittau performed literature search, developed and wrote the paper.

Conflicts of Interest: The authors declare no conflict of interest.

\section{References}

1. Abdullah, R.; Basak, I.; Patil, K.S.; Alves, G.; Larsen, J.P.; Møller, S.G. Parkinson's disease and age: The obvious but largely unexplored link. Exp. Gerontol. 2015, 68, 33-38. [CrossRef] [PubMed]

2. Pringsheim, T.; Jette, N.; Frolkis, A.; Steeves, T.D.L. The prevalence of Parkinson's disease: A systematic review and meta-analysis. Mov. Disord. 2014, 29, 1583-1590. [CrossRef] [PubMed]

3. Jellinger, K.A. Neuropathology of sporadic Parkinson's disease: Evaluation and changes of concepts. Mov. Disord. 2012, 27, 8-30. [CrossRef] [PubMed]

4. Berg, D.; Postuma, R.B.; Bloem, B.; Chan, P.; Dubois, B.; Gasser, T.; Goetz, C.G.; Halliday, G.M.; Hardy, J.; Lang, A.E.; et al. Time to redefine PD? Introductory statement of the MDS task force on the definition of Parkinson's disease. Mov. Disord. 2014, 29, 454-462. [CrossRef] [PubMed]

5. Goldman, J.G.; Postuma, R. Premotor and nonmotor features of Parkinson's disease. Curr. Opin. Neurol. 2014, 27, 434-441. [CrossRef] [PubMed]

6. Sulzer, D. Multiple hit hypotheses for dopamine neuron loss in Parkinson's disease. Trends Neurosci. 2007, 30, 244-250. [CrossRef] [PubMed]

7. Goedert, M.; Spillantini, M.G.; del Tredici, K.; Braak, H. 100 years of Lewy pathology. Nat. Rev. Neurol. 2013, 9, 13-24. [CrossRef] [PubMed]

8. Spillantini, M.G.; Schmidt, M.L.; Lee, V.M.; Trojanowski, J.Q.; Jakes, R.; Goedert, M. $\alpha$-synuclein in Lewy bodies. Nature 1997, 388, 839-840. [CrossRef] [PubMed]

9. Braak, H.; del Tredici, K.; Rüb, U.; de Vos, R.A.I.; Jansen Steur, E.N.H.; Braak, E. Staging of brain pathology related to sporadic Parkinson's disease. Neurobiol. Aging 2003, 24, 197-211. [CrossRef]

10. Buchman, A.S.; Shulman, J.M.; Nag, S.; Leurgans, S.E.; Arnold, S.E.; Morris, M.C.; Schneider, J.A.; Bennett, D.A. Nigral pathology and parkinsonian signs in elders without Parkinson disease. Ann. Neurol. 2012, 71, 258-266. [CrossRef] [PubMed]

11. Block, M.L.; Hong, J.-S. Chronic microglial activation and progressive dopaminergic neurotoxicity. Biochem. Soc. Trans. 2007, 35, 1127-1132. [CrossRef] [PubMed]

12. Hirsch, E.C.; Hunot, S. Neuroinflammation in Parkinson's disease: A target for neuroprotection? Lancet Neurol. 2009, 8, 382-397. [CrossRef]

13. Dauer, W.; Przedborski, S. Parkinson's disease: Mechanisms and models. Neuron 2003, 39, 889-909. [CrossRef]

14. Schober, A. Classic toxin-induced animal models of Parkinson's disease: 6-OHDA and MPTP. Cell Tissue Res. 2004, 318, 215-224. [CrossRef] [PubMed]

15. Langston, J.W.; Ballard, P.; Tetrud, J.W.; Irwin, I. Chronic Parkinsonism in humans due to a product of meperidine-analog synthesis. Science 1983, 219, 979-980. [CrossRef] [PubMed]

16. Przedborski, S.; Jackson-Lewis, V.; Naini, A.B.; Jakowec, M.; Petzinger, G.; Miller, R.; Akram, M. The parkinsonian toxin 1-methyl-4-phenyl-1,2,3,6-tetrahydropyridine (MPTP): A technical review of its utility and safety. J. Neurochem. 2001, 76, 1265-1274. [CrossRef] [PubMed]

17. Nicklas, W.; Vyas, I.; Heikkila, R.E. Inhibition of NADH-linked oxidation in brain mitochondria by 1-methyl-4-phenyl-pyridine, a metabolite of the neurotoxin, 1-methyl-4-phenyl-1,2,5,6-tetrahydropyridine. Life Sci. 1985, 36, 2503-2508. [CrossRef]

18. Nicklas, W.J.; Youngster, S.K.; Kindt, M.V.; Heikkila, R.E. MPTP, MPP ${ }^{+}$and mitochondrial function. Life Sci. 1987, 40, 721-729. [CrossRef]

19. Przedborski, S.; Vila, M. MPTP: A review of its mechanisms of neurotoxicity. Clin. Neurosci. Res. 2001, 1, 407-418. [CrossRef] 
20. Javitch, J.A.; D'Amato, R.J.; Strittmatter, S.M.; Snyder, S.H. Parkinsonism-inducing neurotoxin, $N$-methyl-4-phenyl-1,2,3,6-tetrahydropyridine: Uptake of the metabolite $N$-methyl-4-phenylpyridine by dopamine neurons explains selective toxicity. Proc. Natl. Acad. Sci. USA 1985, 82, 2173-2177. [CrossRef] [PubMed]

21. Javitch, J.A.; Snyder, S.H. Uptake of $\mathrm{MPP}^{+}$by dopamine neurons explains selectivity of parkinsonism-inducing neurotoxin, MPTP. Eur. J. Pharmacol. 1984, 106, 455-456. [CrossRef]

22. Mayer, R.A.; Kindt, M.V.; Heikkila, R.E. Prevention of the nigrostriatal toxicity of 1-methyl-4-phenyl-1,2,3,6-tetrahydropyridine by inhibitors of 3,4-dihydroxyphenylethylamine transport. J. Neurochem. 1986, 47, 1073-1079. [CrossRef] [PubMed]

23. Del Zompo, M.; Piccardi, M.P.; Ruiu, S.; Quartu, M.; Gessa, G.L.; Vaccari, A. Selective MPP ${ }^{+}$uptake into synaptic dopamine vesicles: Possible involvement in MPTP neurotoxicity. Br. J. Pharmacol. 1993, 109, 411-414. [CrossRef] [PubMed]

24. Klaidman, L.K.; Adams, J.D., Jr.; Leung, A.C.; Sam Kim, S.; Cadenas, E. Redox cycling of MPP+: Evidence for a new mechanism involving hydride transfer with xanthine oxidase, aldehyde dehydrogenase, and lipoamide dehydrogenase. Free Radic. Biol. Med. 1993, 15, 169-179. [CrossRef]

25. Mizuno, Y.; Sone, N.; Saitoh, T. Effects of 1-methyl-4-phenyl-1,2,3,6-tetrahydropyridine and 1-methyl-4-phenylpyridinium ion on activities of the enzymes in the electron transport system in mouse brain. J. Neurochem. 1987, 48, 1787-1793. [CrossRef] [PubMed]

26. Rossetti, Z.L.; Sotgiu, A.; Sharp, D.E.; Hadjiconstantinou, M.; Neff, N.H. 1-Methyl-4-phenyl1,2,3,6-tetrahydropyridine (MPTP) and free radicals in vitro. Biochem. Pharmacol. 1988, 37, 4573-4574. [CrossRef]

27. Hasegawa, E.; Takeshige, K.; Oishi, T.; Murai, Y.; Minakami, S. 1-Methyl-4-phenylpyridinium (MPP ${ }^{+}$) induces NADH-dependent superoxide formation and enhances NADH-dependent lipid peroxidation in bovine heart submitochondrial particles. Biochem. Biophys. Res. Commun. 1990, 170, 1049-1055. [CrossRef]

28. Boyce, S.; Kelly, E.; Reavill, C.; Jenner, P.; Marsden, C.D. Repeated administration of N-methyl-4-phenyl 1,2,5,6-tetrahydropyridine to rats is not toxic to striatal dopamine neurones. Biochem. Pharmacol. 1984, 33, 1747-1752. [CrossRef]

29. Chiueh, C.C.; Markey, S.P.; Burns, R.S.; Johannessen, J.N.; Pert, A.; Kopin, I.J. Neurochemical and behavioral effects of systemic and intranigral administration of $N$-methyl-4-phenyl-1,2,3,6-tetrahydropyridine in the rat. Eur. J. Pharmacol. 1984, 100, 189-194. [CrossRef]

30. Sedelis, M.; Hofele, K.; Auburger, G.W.; Morgan, S.; Huston, J.P.; Schwarting, R.K. MPTP susceptibility in the mouse: Behavioral, neurochemical, and histological analysis of gender and strain differences. Behav. Genet. 2000, 30, 171-182. [CrossRef] [PubMed]

31. Sedelis, M.; Hofele, K.; Auburger, G.W.; Morgan, S.; Huston, J.P.; Schwarting, R.K. Evidence for resistance to MPTP in C57BL/6 $\mathrm{x}$ BALB/c F1 hybrids as compared with their progenitor strains. Neuroreport 2000, 11, 1093-1096. [CrossRef] [PubMed]

32. Schmidt, N.; Ferger, B. Neurochemical findings in the MPTP model of Parkinson's disease. J. Neural Transm. 2001, 108, 1263-1282. [CrossRef] [PubMed]

33. Jackson-Lewis, V.; Jakowec, M.; Burke, R.E.; Przedborski, S. Time course and morphology of dopaminergic neuronal death caused by the neurotoxin 1-methyl-4-phenyl-1,2,3,6-tetrahydropyridine. Neurodegener. J. Neurodegener. Disord. Neuroprot. Neuroregener. 1995, 4, 257-269. [CrossRef]

34. Tatton, N.A.; Kish, S.J. In situ detection of apoptotic nuclei in the substantia nigra compacta of 1-methyl-4-phenyl-1,2,3,6-tetrahydropyridine-treated mice using terminal deoxynucleotidyl transferase labelling and acridine orange staining. Neuroscience 1997, 77, 1037-1048. [CrossRef]

35. Vila, M.; Vukosavic, S.; Jackson-Lewis, V.; Neystat, M.; Jakowec, M.; Przedborski, S. $\alpha$-Synuclein up-regulation in substantia nigra dopaminergic neurons following administration of the parkinsonian toxin MPTP. J. Neurochem. 2000, 74, 721-729. [CrossRef] [PubMed]

36. Bezard, E.; Imbert, C.; Deloire, X.; Bioulac, B.; Gross, C.E. A chronic MPTP model reproducing the slow evolution of Parkinson's disease: Evolution of motor symptoms in the monkey. Brain Res. 1997, 766, 107-112. [CrossRef]

37. McGeer, P.L.; McGeer, E.G. Glial reactions in Parkinson's disease. Mov. Disord. 2008, 23, 474-483. [CrossRef] [PubMed] 
38. Tang, Y.; Le, W. Differential roles of M1 and M2 microglia in neurodegenerative diseases. Mol. Neurobiol. 2015, 1-14. [CrossRef] [PubMed]

39. Kohutnicka, M.; Lewandowska, E.; Kurkowska-Jastrzebska, I.; Członkowski, A.; Członkowska, A. Microglial and astrocytic involvement in a murine model of Parkinson's disease induced by 1-methyl-4-phenyl-1,2,3,6-tetrahydropyridine (MPTP). Immunopharmacology 1998, 39, 167-180. [CrossRef]

40. Członkowska, A.; Kohutnicka, M.; Kurkowska-Jastrzebska, I.; Członkowski, A. Microglial reaction in MPTP (1-methyl-4-phenyl-1,2,3,6-tetrahydropyridine) induced Parkinson's disease mice model. Neurodegeneration 1996, 5, 137-143. [CrossRef] [PubMed]

41. Wu, D.C.; Jackson-Lewis, V.; Vila, M.; Tieu, K.; Teismann, P.; Vadseth, C.; Choi, D.-K.; Ischiropoulos, H.; Przedborski, S. Blockade of microglial activation is neuroprotective in the 1-methyl-4-phenyl-1,2,3,6-tetrahydropyridine mouse model of Parkinson disease. J. Neurosci. 2002, 22, 1763-1771. [PubMed]

42. Ciesielska, A.; Joniec, I.; Przybyłkowski, A.; Gromadzka, G.; Kurkowska-Jastrzebska, I.; Członkowska, A.; Członkowski, A. Dynamics of expression of the mRNA for cytokines and inducible nitric synthase in a murine model of the Parkinson's disease. Acta Neurobiol. Exp. 2003, 63, 117-126.

43. Luchtman, D.W.; Shao, D.; Song, C. Behavior, neurotransmitters and inflammation in three regimens of the MPTP mouse model of Parkinson's disease. Physiol. Behav. 2009, 98, 130-138. [CrossRef] [PubMed]

44. Lofrumento, D.D.; Saponaro, C.; Cianciulli, A.; de Nuccio, F.; Mitolo, V.; Nicolardi, G.; Panaro, M.A. MPTP-induced neuroinflammation increases the expression of pro-inflammatory cytokines and their receptors in mouse brain. Neuroimmunomodulation 2011, 18, 79-88. [CrossRef] [PubMed]

45. Yasuda, Y.; Shimoda, T.; Uno, K.; Tateishi, N.; Furuya, S.; Yagi, K.; Suzuki, K.; Fujita, S. The effects of MPTP on the activation of microglia/astrocytes and cytokine/chemokine levels in different mice strains. J. Neuroimmunol. 2008, 204, 43-51. [CrossRef] [PubMed]

46. Pattarini, R.; Smeyne, R.J.; Morgan, J.I. Temporal mRNA profiles of inflammatory mediators in the murine 1-methyl-4-phenyl-1,2,3,6-tetrahydropyrimidine model of Parkinson's disease. Neuroscience 2007, 145, 654-668. [CrossRef] [PubMed]

47. Yasuda, Y.; Shinagawa, R.; Yamada, M.; Mori, T.; Tateishi, N.; Fujita, S. Long-lasting reactive changes observed in microglia in the striatal and substantia nigral of mice after 1-methyl-4-phenyl-1,2,3,6-tetrahydropyridine. Brain Res. 2007, 1138, 196-202. [CrossRef] [PubMed]

48. Barcia, C.; Ros, C.M.; Annese, V.; Carrillo-de Sauvage, M.A.; Ros-Bernal, F.; Gómez, A.; Yuste, J.E.; Campuzano, C.M.; de Pablos, V.; Fernandez-Villalba, E.; Herrero, M.T. ROCK/Cdc42-mediated microglial motility and gliapse formation lead to phagocytosis of degenerating dopaminergic neurons in vivo. Sci. Rep. 2012, 2, 809. [CrossRef] [PubMed]

49. Kurkowska-Jastrzebska, I.; Wrońska, A.; Kohutnicka, M.; Członkowski, A.; Członkowska, A. The inflammatory reaction following 1-methyl-4-phenyl-1,2,3,6-tetrahydropyridine intoxication in mouse. Exp. Neurol. 1999, 156, 50-61. [CrossRef] [PubMed]

50. Brochard, V.; Combadière, B.; Prigent, A.; Laouar, Y.; Perrin, A.; Beray-Berthat, V.; Bonduelle, O.; Alvarez-Fischer, D.; Callebert, J.; Launay, J.-M.; et al. Infiltration of CD4 ${ }^{+}$lymphocytes into the brain contributes to neurodegeneration in a mouse model of Parkinson disease. J. Clin. Investig. 2009, 119, 182-192. [CrossRef] [PubMed]

51. Reynolds, A.D.; Banerjee, R.; Liu, J.; Gendelman, H.E.; Mosley, R.L. Neuroprotective activities of CD4 $4^{+}$CD25 $5^{+}$ regulatory T cells in an animal model of Parkinson's disease. J. Leukoc. Biol. 2007, 82, 1083-1094. [CrossRef] [PubMed]

52. Oppenheim, J.J. Cytokines: Past, present, and future. Int. J. Hematol. 2001, 74, 3-8. [CrossRef] [PubMed]

53. Dinarello, C.A. Historical review of cytokines. Eur. J. Immunol. 2007, 37, S34-S45. [CrossRef] [PubMed]

54. Pestka, S. The interferons: 50 years after their discovery, there is much more to learn. J. Biol. Chem. 2007, 282, 20047-20051. [CrossRef] [PubMed]

55. Owens, T.; Khorooshi, R.; Wlodarczyk, A.; Asgari, N. Interferons in the central nervous system: A few instruments play many tunes. Glia 2014, 62, 339-355. [CrossRef] [PubMed]

56. Mount, M.P.; Lira, A.; Grimes, D.; Smith, P.D.; Faucher, S.; Slack, R.; Anisman, H.; Hayley, S.; Park, D.S. Involvement of interferon- $\gamma$ in microglial-mediated loss of dopaminergic neurons. J. Neurosci. 2007, 27, 3328-3337. [CrossRef] [PubMed] 
57. Barcia, C.; Ros, C.M.; Annese, V.; Gómez, A.; Ros-Bernal, F.; Aguado-Llera, D.; Martínez-Pagán, M.E.; de Pablos, V.; Fernandez-Villalba, E.; Herrero, M.T. IFN- $\gamma$ signaling, with the synergistic contribution of TNF- $\alpha$, mediates cell specific microglial and astroglial activation in experimental models of Parkinson's disease. Cell Death Dis. 2012, 3, e142. [CrossRef] [PubMed]

58. Morganti, J.M.; Nash, K.R.; Grimmig, B.A.; Ranjit, S.; Small, B.; Bickford, P.C.; Gemma, C. The soluble isoform of CX3CL1 is necessary for neuroprotection in a mouse model of Parkinson's disease. J. Neurosci. 2012, 32, 14592-14601. [CrossRef] [PubMed]

59. Cardona, A.E.; Pioro, E.P.; Sasse, M.E.; Kostenko, V.; Cardona, S.M.; Dijkstra, I.M.; Huang, D.; Kidd, G.; Dombrowski, S.; Dutta, R.; et al. Control of microglial neurotoxicity by the fractalkine receptor. Nat. Neurosci. 2006, 9, 917-924. [CrossRef] [PubMed]

60. Kalkonde, Y.V.; Morgan, W.W.; Sigala, J.; Maffi, S.K.; Condello, C.; Kuziel, W.; Ahuja, S.S.; Ahuja, S.K. Chemokines in the MPTP model of Parkinson's disease: Absence of CCL2 and its receptor CCR2 does not protect against striatal neurodegeneration. Brain Res. 2007, 1128, 1-11. [CrossRef] [PubMed]

61. Choi, D.-Y.; Lee, M.K.; Hong, J.T. Lack of CCR5 modifies glial phenotypes and population of the nigral dopaminergic neurons, but not MPTP-induced dopaminergic neurodegeneration. Neurobiol. Dis. 2013, 49, 159-168. [CrossRef] [PubMed]

62. Hébert, G.; Mingam, R.; Arsaut, J.; Dantzer, R.; Demotes-Mainard, J. A role of IL-1 in MPTP-induced changes in striatal dopaminergic and serotoninergic transporter binding: Clues from interleukin-1 type I receptor-deficient mice. Mol. Brain Res. 2005, 136, 267-270. [CrossRef] [PubMed]

63. Bolin, L.M.; Strycharska-Orczyk, I.; Murray, R.; Langston, J.W.; di Monte, D. Increased vulnerability of dopaminergic neurons in MPTP-lesioned interleukin-6 deficient mice. J. Neurochem. 2002, 83, 167-175. [CrossRef] [PubMed]

64. Cardenas, H.; Bolin, L.M. Compromised reactive microgliosis in MPTP-lesioned IL-6 KO mice. Brain Res. 2003, 985, 89-97. [CrossRef]

65. Bradley, J.R. TNF-mediated inflammatory disease. J. Pathol. 2008, 214, 149-160. [CrossRef] [PubMed]

66. Ferger, B.; Leng, A.; Mura, A.; Hengerer, B.; Feldon, J. Genetic ablation of tumor necrosis factor- $\alpha$ (TNF- $\alpha$ ) and pharmacological inhibition of TNF-synthesis attenuates MPTP toxicity in mouse striatum. J. Neurochem. 2004, 89, 822-833. [CrossRef] [PubMed]

67. Zhao, C.; Ling, Z.; Newman, M.B.; Bhatia, A.; Carvey, P.M. TNF- $\alpha$ knockout and minocycline treatment attenuates blood brain barrier leakage in MPTP-treated mice. Neurobiol. Dis. 2007, 26, 36-46. [CrossRef] [PubMed]

68. Sriram, K.; Matheson, J.M.; Benkovic, S.A.; Miller, D.B.; Luster, M.I.; O'Callaghan, J.P. Mice deficient in TNF receptors are protected against dopaminergic neurotoxicity: Implications for Parkinson's disease. FASEB J. 2002, 16, 1474-1476. [CrossRef] [PubMed]

69. Sriram, K.; Matheson, J.M.; Benkovic, S.A.; Miller, D.B.; Luster, M.I.; O'Callaghan, J.P. Deficiency of TNF receptors suppresses microglial activation and alters the susceptibility of brain regions to MPTP-induced neurotoxicity: Role of TNF- $\alpha$. FASEB J. 2006, 20, 670-682. [CrossRef] [PubMed]

70. Rousselet, E.; Callebert, J.; Parain, K.; Joubert, C.; Hunot, S.; Hartmann, A.; Jacque, C.; Perez-Diaz, F.; Cohen-Salmon, C.; Launay, J.-M.; et al. Role of TNF- $\alpha$ Receptors in Mice Intoxicated with the Parkinsonian Toxin MPTP. Exp. Neurol. 2002, 177, 183-192. [CrossRef] [PubMed]

71. Leng, A.; Mura, A.; Feldon, J.; Ferger, B. Tumor necrosis factor- $\alpha$ receptor ablation in a chronic MPTP mouse model of Parkinson's disease. Neurosci. Lett. 2005, 375, 107-111. [CrossRef] [PubMed]

72. Walsh, J.G.; Muruve, D.A.; Power, C. Inflammasomes in the CNS. Nat. Rev. Neurosci. 2014, 15, 84-97. [CrossRef] [PubMed]

73. Martinon, F.; Burns, K.; Tschopp, J. The inflammasome: A molecular platform triggering activation of inflammatory caspases and processing of proIL- $\beta$. Mol. Cell 2002, 10, 417-426. [CrossRef]

74. Schroder, K.; Tschopp, J. The inflammasomes. Cell 2010, 140, 821-832. [CrossRef] [PubMed]

75. Lamkanfi, M.; Dixit, V.M. Inflammasomes and their roles in health and disease. Annu. Rev. Cell Dev. Biol. 2012, 28, 137-161. [CrossRef] [PubMed]

76. Alboni, S.; Cervia, D.; Sugama, S.; Conti, B. Interleukin 18 in the CNS. J. Neuroinflamm. 2010, 7, 9. [CrossRef] [PubMed]

77. Allan, S.M.; Tyrrell, P.J.; Rothwell, N.J. Interleukin-1 and neuronal injury. Nat. Rev. Immunol. 2005, 5, 629-640. [CrossRef] [PubMed] 
78. Klevenyi, P.; Andreassen, O.; Ferrante, R.J.; Schleicher, J.R.; Friedlander, R.M.; Beal, M.F. Transgenic mice expressing a dominant negative mutant interleukin-1 $\beta$ converting enzyme show resistance to MPTP neurotoxicity. Neuroreport 1999, 10, 635-638. [CrossRef] [PubMed]

79. Codolo, G.; Plotegher, N.; Pozzobon, T.; Brucale, M.; Tessari, I.; Bubacco, L.; de Bernard, M. Triggering of inflammasome by aggregated $\alpha$-synuclein, an inflammatory response in synucleinopathies. PLoS ONE 2013, 8, e55375. [CrossRef] [PubMed]

80. Gustin, A.; Kirchmeyer, M.; Koncina, E.; Felten, P.; Losciuto, S.; Heurtaux, T.; Tardivel, A.; Heuschling, P.; Dostert, C. NLRP3 inflammasome is expressed and functional in mouse brain microglia but not in astrocytes. PLOS ONE 2015, 10, e0130624. [CrossRef] [PubMed]

81. Yan, Y.; Jiang, W.; Liu, L.; Wang, X.; Ding, C.; Tian, Z.; Zhou, R. Dopamine controls systemic inflammation through inhibition of NLRP3 inflammasome. Cell 2015, 160, 62-73. [CrossRef] [PubMed]

82. Wang, L.; Zhai, Y.-Q.; Xu, L.-L.; Qiao, C.; Sun, X.-L.; Ding, J.-H.; Lu, M.; Hu, G. Metabolic inflammation exacerbates dopaminergic neuronal degeneration in response to acute MPTP challenge in type 2 diabetes mice. Exp. Neurol. 2014, 251, 22-29. [CrossRef] [PubMed]

83. Vroon, A.; Drukarch, B.; Bol, J.G.J.M.; Cras, P.; Brevé, J.J.P.; Allan, S.M.; Relton, J.K.; Hoogland, P.V.J.M.; van Dam, A.-M. Neuroinflammation in Parkinson's patients and MPTP-treated mice is not restricted to the nigrostriatal system: Microgliosis and differential expression of interleukin-1 receptors in the olfactory bulb. Exp. Gerontol. 2007, 42, 762-771. [CrossRef] [PubMed]

84. Sugama, S.; Wirz, S.A.; Barr, A.M.; Conti, B.; Bartfai, T.; Shibasaki, T. Interleukin-18 null mice show diminished microglial activation and reduced dopaminergic neuron loss following acute 1-methyl-4-phenyl-1,2,3,6-tetrahydropyridine treatment. Neuroscience 2004, 128, 451-458. [CrossRef] [PubMed]

85. Aron, L.; Klein, R. Repairing the parkinsonian brain with neurotrophic factors. Trends Neurosci. 2011, 34, 88-100. [CrossRef] [PubMed]

86. Hegarty, S.V.; O'Keeffe, G.W.; Sullivan, A.M. Neurotrophic factors: From neurodevelopmental regulators to novel therapies for Parkinson's disease. Neural Regen. Res. 2014, 9, 1708-1711. [PubMed]

87. Weissmiller, A.M.; Wu, C. Current advances in using neurotrophic factors to treat neurodegenerative disorders. Transl. Neurodegener. 2012, 1, 14. [CrossRef] [PubMed]

88. Hyman, C.; Hofer, M.; Barde, Y.A.; Juhasz, M.; Yancopoulos, G.D.; Squinto, S.P.; Lindsay, R.M. BDNF is a neurotrophic factor for dopaminergic neurons of the substantia nigra. Nature 1991, 350, 230-232. [CrossRef] [PubMed]

89. Skaper, S.D. The neurotrophin family of neurotrophic factors: An overview. Methods Mol. Biol. Clifton NJ 2012, 846, 1-12.

90. Chen, L.-W.; Hu, H.-J.; Liu, H.-L.; Yung, K.K.L.; Chan, Y.S. Identification of brain-derived neurotrophic factor in nestin-expressing astroglial cells in the neostriatum of 1-methyl-4-phenyl1,2,3,6-tetrahydropyridine-treated mice. Neuroscience 2004, 126, 941-953. [CrossRef] [PubMed]

91. Gerecke, K.M.; Jiao, Y.; Pagala, V.; Smeyne, R.J. Exercise does not protect against MPTP-induced neurotoxicity in BDNF haploinsufficient mice. PLoS ONE 2012, 7, e43250. [CrossRef] [PubMed]

92. Baydyuk, M.; Nguyen, M.T.; Xu, B. Chronic deprivation of TrkB signaling leads to selective late-onset nigrostriatal dopaminergic degeneration. Exp. Neurol. 2011, 228, 118-125. [CrossRef] [PubMed]

93. Garcia, E.; Rios, C.; Sotelo, J. Ventricular injection of nerve growth factor increases dopamine content in the striata of MPTP-treated mice. Neurochem. Res. 1992, 17, 979-982. [CrossRef] [PubMed]

94. Chen, L.-W.; Zhang, J.-P.; Kwok-Yan Shum, D.; Chan, Y.-S. Localization of nerve growth factor, neurotrophin-3, and glial cell line-derived neurotrophic factor in nestin-expressing reactive astrocytes in the caudate-putamen of 1-methyl-4-phenyl-1,2,3,6-tetrahydropyridine-treated C57/Bl mice. J. Comp. Neurol. 2006, 497, 898-909. [CrossRef] [PubMed]

95. Airavaara, M.; Voutilainen, M.H.; Wang, Y.; Hoffer, B. Neurorestoration. Parkinsonism Relat. Disord. 2012, 18, S143-S146. [CrossRef]

96. Lin, L.F.; Doherty, D.H.; Lile, J.D.; Bektesh, S.; Collins, F. GDNF: A glial cell line-derived neurotrophic factor for midbrain dopaminergic neurons. Science 1993, 260, 1130-1132. [CrossRef] [PubMed]

97. Garcia de Yebenes, J.; Yebenes, J.; Mena, M.A. Neurotrophic factors in neurodegenerative disorders: Model of Parkinson's disease. Neurotox. Res. 2000, 2, 115-137. [CrossRef] [PubMed] 
98. Granholm, A.C.; Reyland, M.; Albeck, D.; Sanders, L.; Gerhardt, G.; Hoernig, G.; Shen, L.; Westphal, H.; Hoffer, B. Glial cell line-derived neurotrophic factor is essential for postnatal survival of midbrain dopamine neurons. J. Neurosci. 2000, 20, 3182-3190. [PubMed]

99. Date, I.; Aoi, M.; Tomita, S.; Collins, F.; Ohmoto, T. GDNF administration induces recovery of the nigrostriatal dopaminergic system both in young and aged parkinsonian mice. Neuroreport 1998, 9, 2365-2369. [CrossRef] [PubMed]

100. Tomac, A.; Lindqvist, E.; Lin, L.F.; Ogren, S.O.; Young, D.; Hoffer, B.J.; Olson, L. Protection and repair of the nigrostriatal dopaminergic system by GDNF in vivo. Nature 1995, 373, 335-339. [CrossRef] [PubMed]

101. Cheng, F.C.; Ni, D.R.; Wu, M.C.; Kuo, J.S.; Chia, L.G. Glial cell line-derived neurotrophic factor protects against 1-methyl-4-phenyl-1,2,3,6-tetrahydropyridine (MPTP)-induced neurotoxicity in C57BL/6 mice. Neurosci. Lett. 1998, 252, 87-90. [CrossRef]

102. Schober, A.; Peterziel, H.; von Bartheld, C.S.; Simon, H.; Krieglstein, K.; Unsicker, K. GDNF applied to the MPTP-lesioned nigrostriatal system requires TGF- $\beta$ for its neuroprotective action. Neurobiol. Dis. 2007, 25, 378-391. [CrossRef] [PubMed]

103. Biju, K.C.; Zhou, Q.; Li, G.; Imam, S.Z.; Roberts, J.L.; Morgan, W.W.; Clark, R.A.; Li, S. Macrophage-mediated GDNF delivery protects against dopaminergic neurodegeneration: A therapeutic strategy for Parkinson's disease. Mol. Ther. J. Am. Soc. Gene Ther. 2010, 18, 1536-1544. [CrossRef] [PubMed]

104. Biju, K.C.; Santacruz, R.A.; Chen, C.; Zhou, Q.; Yao, J.; Rohrabaugh, S.L.; Clark, R.A.; Roberts, J.L.; Phillips, K.A.; Imam, S.Z.; et al. Bone marrow-derived microglia-based neurturin delivery protects against dopaminergic neurodegeneration in a mouse model of Parkinson's disease. Neurosci. Lett. 2013, 535, $24-29$. [CrossRef] [PubMed]

105. Kowsky, S.; Pöppelmeyer, C.; Kramer, E.R.; Falkenburger, B.H.; Kruse, A.; Klein, R.; Schulz, J.B. RET signaling does not modulate MPTP toxicity but is required for regeneration of dopaminergic axon terminals. Proc. Natl. Acad. Sci. USA 2007, 104, 20049-20054. [CrossRef] [PubMed]

106. Boger, H.A.; Middaugh, L.D.; Zaman, V.; Hoffer, B.; Granholm, A.-C. Differential effects of the dopamine neurotoxin MPTP in animals with a partial deletion of the GDNF receptor, GFR $\alpha 1$, gene. Brain Res. 2008, 1241, 18-28. [CrossRef] [PubMed]

107. Krieglstein, K.; Suter-Crazzolara, C.; Unsicker, K. Development of mesencephalic dopaminergic neurons and the transforming growth factor- $\beta$ superfamily. J. Neural Transm. Suppl. 1995, 46, 209-216. [PubMed]

108. Krieglstein, K.; Henheik, P.; Farkas, L.; Jaszai, J.; Galter, D.; Krohn, K.; Unsicker, K. Glial cell line-derived neurotrophic factor requires transforming growth factor- $\beta$ for exerting its full neurotrophic potential on peripheral and CNS neurons. J. Neurosci. 1998, 18, 9822-9834. [PubMed]

109. Schober, A.; Hertel, R.; Arumäe, U.; Farkas, L.; Jaszai, J.; Krieglstein, K.; Saarma, M.; Unsicker, K. Glial cell line-derived neurotrophic factor rescues target-deprived sympathetic spinal cord neurons but requires transforming growth factor- $\beta$ as cofactor in vivo. J. Neurosci. 1999, 19, 2008-2015. [PubMed]

110. Andrews, Z.B.; Zhao, H.; Frugier, T.; Meguro, R.; Grattan, D.R.; Koishi, K.; McLennan, I.S. Transforming growth factor $\beta 2$ haploinsufficient mice develop age-related nigrostriatal dopamine deficits. Neurobiol. Dis. 2006, 21, 568-575. [CrossRef] [PubMed]

111. Sánchez-Capelo, A.; Colin, P.; Guibert, B.; Biguet, N.F.; Mallet, J. Transforming growth factor $\beta 1$ overexpression in the nigrostriatal system increases the dopaminergic deficit of MPTP mice. Mol. Cell. Neurosci. 2003, 23, 614-625. [CrossRef]

112. Hadjiconstantinou, M.; Fitkin, J.G.; Dalia, A.; Neff, N.H. Epidermal growth factor enhances striatal dopaminergic parameters in the 1-methyl-4-phenyl-1,2,3,6-tetrahydropyridine-treated mouse. J. Neurochem. 1991, 57, 479-482. [CrossRef] [PubMed]

113. Date, I.; Notter, M.F.; Felten, S.Y.; Felten, D.L. MPTP-treated young mice but not aging mice show partial recovery of the nigrostriatal dopaminergic system by stereotaxic injection of acidic fibroblast growth factor (aFGF). Brain Res. 1990, 526, 156-160. [CrossRef]

114. Otto, D.; Unsicker, K. Basic FGF reverses chemical and morphological deficits in the nigrostriatal system of MPTP-treated mice. J. Neurosci. 1990, 10, 1912-1921. [PubMed]

115. Chadi, G.; Møller, A.; Rosén, L.; Janson, A.M.; Agnati, L.A.; Goldstein, M.; Ogren, S.O.; Pettersson, R.F.; Fuxe, K. Protective actions of human recombinant basic fibroblast growth factor on MPTP-lesioned nigrostriatal dopamine neurons after intraventricular infusion. Exp. Brain Res. 1993, 97, 145-158. [CrossRef] [PubMed] 
116. Otto, D.; Unsicker, K. FGF-2 modulates dopamine and dopamine-related striatal transmitter systems in the intact and MPTP-lesioned mouse. Eur. J. Neurosci. 1993, 5, 927-932. [CrossRef] [PubMed]

117. Unsicker, K. FGF-2 in the MPTP model of Parkinson's disease: Effects on astroglial cells. Glia 1994, 11, 47-56.

118. Wirth, S.B.; Rufer, M.; Unsicker, K. Early effects of FGF-2 on glial cells in the MPTP-lesioned striatum. Exp. Neurol. 1996, 137, 191-200. [CrossRef] [PubMed]

119. Zechel, S.; Jarosik, J.; Kiprianova, I.; Schober, A.; Unsicker, K.; von Bohlen und Halbach, O. FGF-2 deficiency does not alter vulnerability of the dopaminergic nigrostriatal system towards MPTP intoxication in mice. Eur. J. Neurosci. 2006, 23, 1671-1675. [CrossRef] [PubMed]

120. Russo, V.C.; Gluckman, P.D.; Feldman, E.L.; Werther, G.A. The insulin-like growth factor system and its pleiotropic functions in brain. Endocr. Rev. 2005, 26, 916-943. [CrossRef] [PubMed]

121. Nadjar, A.; Berton, O.; Guo, S.; Leneuve, P.; Dovero, S.; Diguet, E.; Tison, F.; Zhao, B.; Holzenberger, M.; Bezard, E. IGF-1 signaling reduces neuro-inflammatory response and sensitivity of neurons to MPTP. Neurobiol. Aging 2009, 30, 2021-2030. [CrossRef] [PubMed]

122. Zachrisson, O.; Zhao, M.; Andersson, A.; Dannaeus, K.; Häggblad, J.; Isacson, R.; Nielsen, E.; Patrone, C.; Rönnholm, H.; Wikstrom, L.; et al. Restorative effects of platelet derived growth factor-BB in rodent models of Parkinson's disease. J. Parkinsons Dis. 2011, 1, 49-63. [PubMed]

123. Nikkhah, G.; Odin, P.; Smits, A.; Tingström, A.; Othberg, A.; Brundin, P.; Funa, K.; Lindvall, O. Platelet-derived growth factor promotes survival of rat and human mesencephalic dopaminergic neurons in culture. Exp. Brain Res. 1993, 92, 516-523. [CrossRef] [PubMed]

124. Othberg, A.; Odin, P.; Ballagi, A.; Ahgren, A.; Funa, K.; Lindvall, O. Specific effects of platelet derived growth factor (PDGF) on fetal rat and human dopaminergic neurons in vitro. Exp. Brain Res. 1995, 105, 111-122. [CrossRef] [PubMed]

125. Root, R.K.; Dale, D.C. Granulocyte Colony-Stimulating Factor and Granulocyte-Macrophage Colony-Stimulating Factor: Comparisons and Potential for Use in the Treatment of Infections in Nonneutropenic Patients. J. Infect. Dis. 1999, 179, S342-S352. [CrossRef] [PubMed]

126. Schäbitz, W.-R.; Kollmar, R.; Schwaninger, M.; Juettler, E.; Bardutzky, J.; Schölzke, M.N.; Sommer, C.; Schwab, S. Neuroprotective effect of granulocyte colony-stimulating factor after focal cerebral ischemia. Stroke J. Cereb. Circ. 2003, 34, 745-751. [CrossRef] [PubMed]

127. Schneider, A.; Krüger, C.; Steigleder, T.; Weber, D.; Pitzer, C.; Laage, R.; Aronowski, J.; Maurer, M.H.; Gassler, N.; Mier, W.; et al. The hematopoietic factor G-CSF is a neuronal ligand that counteracts programmed cell death and drives neurogenesis. J. Clin. Investig. 2005, 115, 2083-2098. [CrossRef] [PubMed]

128. Meuer, K.; Pitzer, C.; Teismann, P.; Krüger, C.; Göricke, B.; Laage, R.; Lingor, P.; Peters, K.; Schlachetzki, J.C.M.; Kobayashi, K.; et al. Granulocyte-colony stimulating factor is neuroprotective in a model of Parkinson's disease. J. Neurochem. 2006, 97, 675-686. [CrossRef] [PubMed]

129. Song, S.; Sava, V.; Rowe, A.; Li, K.; Cao, C.; Mori, T.; Sanchez-Ramos, J. Granulocyte-colony stimulating factor (G-CSF) enhances recovery in mouse model of Parkinson's disease. Neurosci. Lett. 2011, 487, 153-157. [CrossRef] [PubMed]

130. Cao, X.-Q.; Arai, H.; Ren, Y.-R.; Oizumi, H.; Zhang, N.; Seike, S.; Furuya, T.; Yasuda, T.; Mizuno, Y.; Mochizuki, H. Recombinant human granulocyte colony-stimulating factor protects against MPTP-induced dopaminergic cell death in mice by altering Bcl-2/Bax expression levels. J. Neurochem. 2006, 99, 861-867. [CrossRef] [PubMed]

131. Kim, N.K.; Choi, B.H.; Huang, X.; Snyder, B.J.; Bukhari, S.; Kong, T.-H.; Park, H.; Park, H.C.; Park, S.R.; $\mathrm{Ha}, \mathrm{Y}$. Granulocyte-macrophage colony-stimulating factor promotes survival of dopaminergic neurons in the 1-methyl-4-phenyl-1,2,3,6-tetrahydropyridine-induced murine Parkinson's disease model. Eur. J. Neurosci. 2009, 29, 891-900. [CrossRef] [PubMed]

132. Kosloski, L.M.; Kosmacek, E.A.; Olson, K.E.; Mosley, R.L.; Gendelman, H.E. GM-CSF induces neuroprotective and anti-inflammatory responses in 1-methyl-4-phenyl-1,2,3,6-tetrahydropyridine intoxicated mice. J. Neuroimmunol. 2013, 265, 1-10. [CrossRef] [PubMed]

133. Lindholm, P.; Saarma, M. Novel CDNF/MANF family of neurotrophic factors. Dev. Neurobiol. 2010, 70, 360-371. [CrossRef] [PubMed] 
134. Lindholm, P.; Voutilainen, M.H.; Laurén, J.; Peränen, J.; Leppänen, V.-M.; Andressoo, J.-O.; Lindahl, M.; Janhunen, S.; Kalkkinen, N.; Timmusk, T.; et al. Novel neurotrophic factor CDNF protects and rescues midbrain dopamine neurons in vivo. Nature 2007, 448, 73-77. [CrossRef] [PubMed]

135. Airavaara, M.; Harvey, B.K.; Voutilainen, M.H.; Shen, H.; Chou, J.; Lindholm, P.; Lindahl, M.; Tuominen, R.K.; Saarma, M.; Hoffer, B.; et al. CDNF protects the nigrostriatal dopamine system and promotes recovery after MPTP treatment in mice. Cell Transplant. 2012, 21, 1213-1223. [CrossRef] [PubMed]

(c) 2016 by the authors; licensee MDPI, Basel, Switzerland. This article is an open access article distributed under the terms and conditions of the Creative Commons by Attribution (CC-BY) license (http:/ / creativecommons.org/licenses/by/4.0/). 